\title{
Danmarks Brunkulsreserver
}

Rapport Fase 2

Udført for Energiministeriet
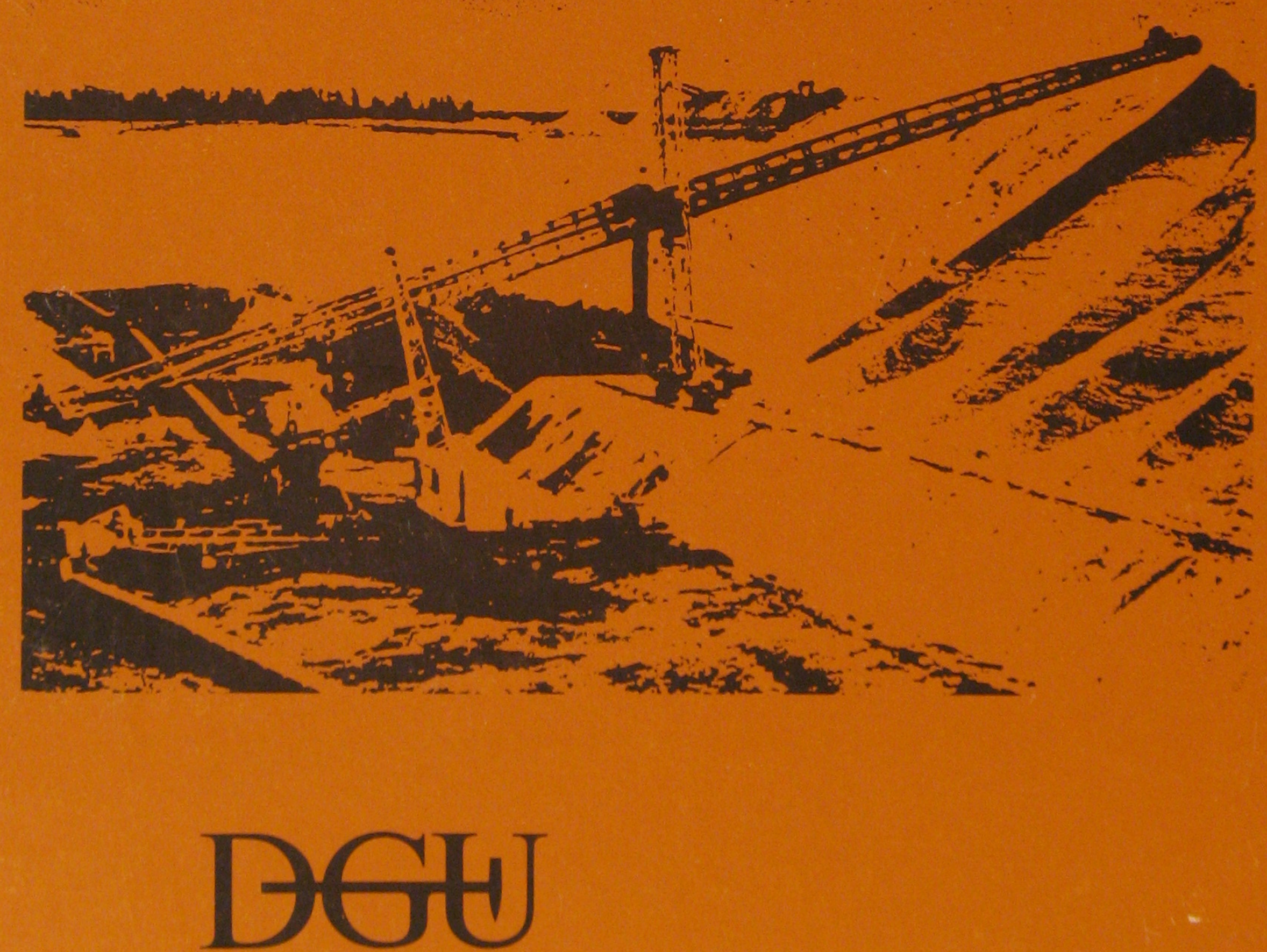

Danmarks Geologiske Undersøgelse 


\section{Danmarks \\ Brunkulsreserver}

\section{Rapport Fase 2}

Udført for Energiministeriet

Udarbejdet i Kvartærgeologisk afdeling

Af cand. scient. Allan Grambo-Rasmussen

Maj 1984

DGU-rapportserie D nr. 2 1984

ISBN 8788640043 


\section{INDHOLDSFORTEGNELSE}

1.0

2.0

2.1

3.0

3.1

3.2

4.0

4.1

4.1 .1

4.1. 2

4.2

4.2 .1

4.2 .1 .1

4. 2.1 .2

4.2 .1 .3

4.2 .1 .4

4.2 .1 .5

4.2 .2

5.0

5.1

5.2

5.3

5.4

6.0

7.0

8.0

9.0

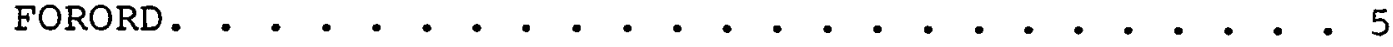

RESUME OG SUMMARY . . . . . . . . . . . . . . 7

INDLEDNING. . . . . . . . . . . . . . . . . . 10

Baggrund Og Formål. . . . . . . . . . . . . 10 ADMINISTRATIVE FORHOLD. . . . . . . . . . . . . . . II

Følgegruppe . . . . . . . . . . . . . . . . . 12

Arbejdsgruppe . . . . . . . . . . . . . . . 13

PROJEKTETS GENNEMFØRELSE. • . . . . . . . . . . . . . 14

Undersøgelsesområdet. . . . . . . . . • . . . . 14 Beliggenhed Og Tilrådighedstående Data. . . . . 14 Geologi . . . . . . . . . . . . . . . . . . .

Arbejdsforløb . . . . . . . . . . . . . . . . . . . . . Behandling Og Tilblivelse Af Data . . . . . . 19 Digitalisering (diskrete Data). . . . . . . 19 Kort Og Profiler. . . . . . . . . . . . 20 Boredata I Tabelformat. . . . . . . . . . 22 Statistik For Tabeldata . . . . . . . . . 22 Kemidata. • . • . . . . . . . . . . 24 EDB-programmer. . . . . . . . . . . . . 28 RESUltater. . . . . . . . . . . . . . . . . 30

Brunkulsmængden - Samlede Oprindelige . . . . . . . 31 Brunkulsmængden - Indvundet . . . . . . . . . 32 Brunkulsreserven. . . . . . . . . . . . . . 32

Resultater Af Kemianalyser. . . . . . . . . . 34 EVALUERING AF RESULTATET. • . . . . . . . . . . . . 34 MILJØASPEKTER VED BRUNKULSBRYDNINGEN OG ANVENDELSEN .37 KONKLUSION. • . • . . . . . . . . . . . . . 38

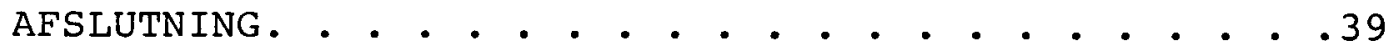
LITTERATUROVERSIGT FIGURER $43-67$ 
FORORD

DGU har $i$ tre perioder, de 3 brunkulskampagner, udf $\phi$ rt omfattende efters $\phi g n i n g e r$ af brunkuls forekomster.

Den I brunkulskampagne, under ledelse af Statsgeolog V. Milthers, blev udf $\phi r t ~ i ~ 1921$, for Indenrigsministeriets tekniske udvalg.

Fra 1941-1949 forestod Statsgeolog Keld Milthers II brunkulskampagne som blev gennemført ved særbevillinger fra Arbejds - og Socialministeriet og Undervisningsministeriet.

Keld Milthers skulle også have haft ledelsen for III brunkulskampagne, men på grund af sygdom blev denne overdraget mig.

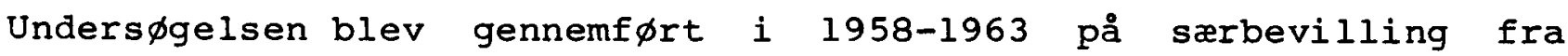
Ministeriet for offentlige arbejder.

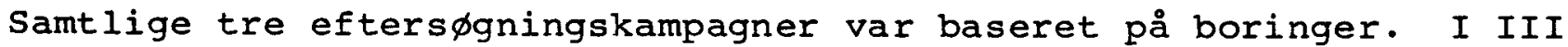
kampagne blev boreprogrammet suppleret med geo-elektriske unders $\phi$ gelser.

Under og efter hver kampagne blev de indsamlede oplysninger fra forskellige områder forelфbigt bearbejdet og selve unders $\phi g e l s e n$ naturligvis afrapporteret. På samme tidspunkt blev det indsamlede materiale, ca. 12.000 DGU-boringer samt indsamlede private boringer, og resulteterne af de geo-elektriske unders $\phi g e l s e r$, registreret og arkiveret på DGU.

En bearbejdelse af det meget store datamateriele blev fors $\phi g t$ umiddelbart efter III kampagne, men andre arbejdsopgaver forhindrede en fortsættelse. Endnu et fors $\phi g$ blev gjort i 1960-erne, men stoppede på grund af manglende фkonomiske og personalemæsige ressourcer.

Den stigende energi-bevisthed og -efterspфrgsel gennem de senere år, samt udviklingen af ny teknologi, især på edb-området, som muligg $\varnothing r$ behandling af meget store datamængder, tilskyndede DGU til at foreslå brunkulsreserverne kortlagt og bearbejdet ved anvendelse af edb-teknik. 
Til dette formål fik DGU til 1. fase af projektet "Danmarks brunkulsreserver" i 1980 фkonomisk stфtte fra Energiministeriet, og i 1982 til 2. fase halv støtte, idet DGU financierede den anden halvael.

Uden den $\phi$ konomiske stфtte fra Energiministeriet, og ikke mindst, ved den meget store arbejdsindsats som cand. scient. Allan Grambo-Rasmussen har ydet, ville det ikke have været muligt at gennemfore projektet, og derved nå de resultater der var opstillet i projekthåndbogen.

Erik Heller

Projektleder

Kvartærgeologisk

afdeling 
I Danmark findes der brunkul i Midt- og Vestjylland. Generelt forekommer brunkullet $i$ dybder fra 15 til $25 \mathrm{~m}$, med lagtykkelser fra nogle få centimeter og op til 3 eller $4 \mathrm{~m}$.

I 1921, under og efter 2. verdenskrig, samt $i$ perioden 1958-63 blev der udført en lang række systematiske boringer efter brunkul. Oplysninger fra boringerne er lфbende registreret og arkiveret ved Danmarks Geologiske Unders $\phi g e l s e$ (DGU).

I september 1980 startede DGU et fasedelt projekt, financieret af EFP-midler. Projektet behandler beliggenhed og kvalitet af brunkullene under anvendelse af edb-teknik. Der er $i$ projektet indbygget tre faser. De to forste faser er gennemfort og behandles $i$ denne rapport, mens de miljømæssige konsekvenser, ved udnyttelse og anvendelse af brunkullene, vil kunne belyses $i$ projektets tredje fase. Iværksttelsen af fase tre er afhængig af resultaterne $i$ projektets anden fase.

I fase 1 er boringernes lagdata konverteret til edb-læsbare symboler og indlagt $i$ en databank. Fra databanken er udtegnet et kort i l:200.000 med angivelse af brunkulsforekomster. Samtidig er udf $\phi r t$ en forel $\phi$ big mængdeberegning.

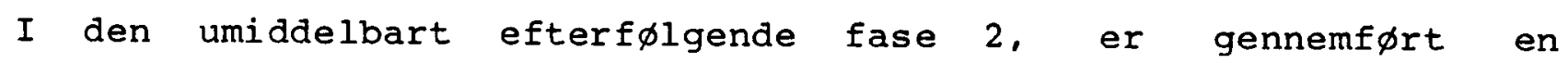
rettelsesprocedure af boringernes oplysninger $i$ databanken. En række edb-programmer er udviklet til brug ved den geologiske bearbejdelse af boringerne. Boringernes geografiske placering er plottet, og mængden af brunkul $i$ boringerne er udregnet. EDB-plotteprogrammer er anvendt til udtegning af brunkulsområder og tykkelsen af de tilstedeværende brunkul. Endelig er beregnet mængden af brunkul pr. kortblad i 1:50.000. Den samlede mængde brunkul pr. kortblad, angiver den totale brunkulsmængde, som er tilstede $i$ Midt-og Vestjylland.

Til beskrivelse af brunkullenes lejringsdybde, er beregnet en serie fysiske parametre. En af disse bærer betegnelsen 'graveindex'. Kemiske analyser indgår $i$ vurderingen af brunkullenes kvalitet. Graveindex, brunkulsmængden, den edb-beregnede st $\phi r r e l s e$ af bortgravet brunkul og resultaterne af de kemiske analyser, angiver beliggenhed, mængde og kvalitet af den sandsynlige brunkulsreserve i Danmark. 
In Denmark brown coal deposits are located in central and western Jutland. Generally the brown coal layers are situated at depths of 15 to 25 metres and with thicknesses varying from a few centimetres up to 4 or 5 metres.

During and after Wold War I and II and in the period from 1958 to 1963 a large number of systematic borings were carried out in order to locate the brown coal seams. The information obtained from these borings was continuously registered at the Geological survey of Denmark (DGU).

In september 1980 DGU initiated a project financed by EFP-funds (energy-investigations-project-funds) dealing with the location and quality of brown coal by use of EDP-techniques.

The project was divided into three phases. The first and second of these phases have been completed and form the subject of this report, while a third phase is to deal with the environmental consequences of utilizing the brown coal.

During the first phase of the project the boring information was converted into EDP-readable symbols and stored in a data bank. From this data bank a map on the scale of 1:200,000 was plotted locating the brown coal areas, and on the basis of these data a preliminary calculation of the amount of brown coal was made.

During the second phase the boring information in the data bank was checked and corrected if necessary. Then a series of programmes were developed in order to support the geological investigations. The geographical locations of the borings were plotted, and the amount of brown coals of each boring calculated. EDP-plotprogrammes were used to plot the brown coal areas and to calculate the thickness of the brown coal at hand. Finally the amount of brown coal was calculated for each individual map sheet on the scale of 1:50,000. The sum of these calculations gives the total amount of brown coal in the investigated area.

In order to estimate the depth at which the brown coal is bedded, some physical parameters were calculated. One of these is called the "digging index". Chemical analyses form part of the evaluation of the quality of the brown coal. The digging index, the total amount of brown coal, the EDP-calculated amount of brown coal already exploited, and the results of the chemical analyses indicate the occurrence, quantity and quality of the potential brown coal reserves in Denmark. 


\subsection{INDLEDNING}

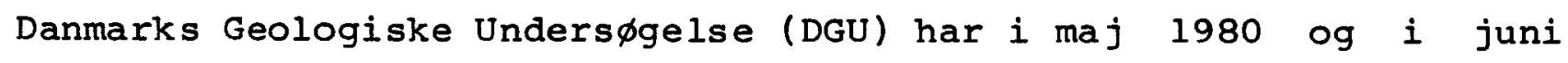
1982 opnået $\phi k o n o m i s k$ stфtte fra Energiministeriet til et udredningsprojekt om opgфrelse af Danmarks brunkulsreserver. støtten er bevilget af Energiministeriets pulje til energiforskningsprojekter (EFP-80 og EFP-82).

Udredningsprojektet er delt $i$ fase 1,2 og 3 . Fase 1 er afrapporteret til Energiministeriet med udgangen af januar 1982 . Indholdet $i$ denne rapport omhandler $i$ hovedsagen fase 2 , men erstatter $i$ vid udstrækning tillige indhold og resultater af f $\phi$ rste fase.

Der tages stilling til gennemførelse af fase 3 , når de opnåede resultaterne $i$ fase 2 er vurderet.

\subsection{Baggrund Og Formål}

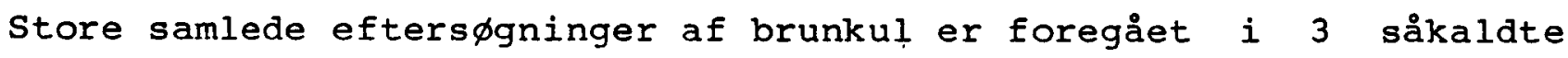
brunkulskampagner, $i$ 1921, under og efter 2. verdenskrig samt $i$ perioden 1958-63. Undersфgelserne er forestået af DGU, hvor resultaterne er opbevaret. Endvidere har Geologisk Institut ved Arhus Universitet, med stфtte fra Statens naturvidenskabelige Forskningsråd, fulgt dette arbejde op med detaljerede geologiske undersфgelser af det tidligere så vigtige brunkulsproducerende område sфby-Falsterholt ved Herning.

Interessen for brunkul har været stærkt svingende, afhængig af brændselsefterspфrgslen, og der har ikke tidligere været afsat forn $\phi$ dne ressourcer til at færdigbearbejde unders $\phi$ gelsesresultaterne.

En række oplysninger er dog sammenstillet $i$ tidens $1 \phi b$ og anvendt f.eks. i en række jyske amtskommuners råstofregistreringsarbejde.

DGU's arkivmateriale vedr $\phi r e n d e$ brunkul er så omfattende, at en systematisk manuel bearbejaning med henblik på kortlægning af kullenes udbredelse og kvalitet er uoverkommelig. 
Imidlertid har den stigende brændselseftersp $\phi$ rgsel gennem de senere år og udvikling af edb-systemer, som muligg $\phi r$ behandling af den store datamængde, tilskyndet DGU til at foresla brunkulsreserverne kortlagt under anvendelse af moderne edb-teknik.

Interessen for kendskab til brunkulsressourcens stфrrelse ses senest udtrykt $i$ spørgsmål til folketingets Landbrugs- og fiskeriudvalg den 30/4 1980 (Alm.del/L-bilag 55), hvorfra citeres spфrgsmål L.48: "Hvor store er de danske brunkulsreserver og hvor stor brændværdi har de omregnet til gasolie?".-

DGU's projekt vedrørende kortlægning af de danske brunkulsforekomster er et faseopdelt projekt. Formålet med den første fase, var primært, ved en systematisering og bearbejaning af eksisterende arkivmateriale, at opg $\phi r e$ de samlede brunkulsmængder. I projektets anden fase er gennemfort en nærmere vurdering af brunkulsforekomsternes udbredelse, mængde og omfang $i$ relation til tilgængelighed og brydeværdighed.

De miljфmæssige konsekvenser ved en eventuel indvinding og anvendelse af brunkullene planlægges belyst $i$ brunkulsprojektets tredje fase, jfr. miljфministeriets skrivelse af 20 . maj 1980 til Energiministeriet og kapitel $7.0 \mathrm{i}$ denne rapport.

I nærværende rapport omtales resultaterne af brunkulsprojektets første fase og anden fase.

\subsection{ADMINISTRATIVE FORHOLD}

Forste fase af brunkulsprojektet er gennemfort $i$ tiden 1 . september 1980 til 31. december 1981 med financiel st $\phi t t e$ fra Energiministeriet på $415.000 \mathrm{kr}$.

Anden fase er gennemfort $i$ tiden 1 . februar 1982 til 31. marts 1984 som et financielt samarbejde mellem Energiministeriet og DGU, idet hver har investeret $500.000 \mathrm{kr}$. i fase 2 af projektet.

Projektet er gennemf $\phi r t$ af Kvartærgeologisk afdeling ved DGU med cand.scient Allan Grambo-Rasmussen som daglig leder. I de første 5 
måneder af projektet har cand. scient. Anne-Lise Jensen varetaget den daglige ledelse.

Projektleder har været Statsgeolog Erik Heller, leder af Kvartærgeologisk afdeling. Herudover har Prof. 1ic. scient Arne Villumsen (DTH) under fase 1, deltaget $i$ styringen og ledelsen af projektet.

\subsection{F $\not$ lgegruppe}

DGU har inviteret Energiministeriet, Fredningsstyrelsen og Amtsrådsforeningen $t i l$ at indtræde $i$ en følgegruppe for projektet. Følgegruppen har følgende sammensætning:

Geolog, cand.scient. Elise Baastrup, Ringkфbings Amtskommune

Geolog, cand.scient. Knud Petersen, Vejle Amtskommune

Geolog, cand.scient. Steen Andersen, Fredningsstyrelsen

Chefgeolog, Erik Stenestad, DGU

Statsgeolog, cand.mag. Erik Heller, DGU

Professor, lic.scient. Arne Villumsen, DTH

Energiministeriet har $\varnothing$ nsket at modtage materiale m.v. til fфlgegruppen uden at være medlem af gruppen.

Under forl $\phi$ bet af fase 2 er afgåede direkt $\phi$ r for DGU, dr.phil ole Berthelsen udtrådt af følgegruppen og erstattet med chefgeolog Erik Stenestad. Cand.scient Arne Rosenkrands Larsen er ligeledes

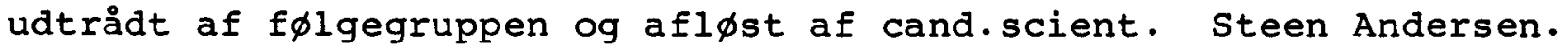

Der har den 6. december 1983 været afholdt orienterende m $\phi$ de for fфlgegruppen om forl $\phi$ bet af projektets anden fase. 


\subsection{Arbejdsgruppe}

Medarbejdere fra DGU's Kvartærgeologiske afdeling, EDB-sektionen og kemisk laboratorium har deltaget i arbejdet. 


\section{4 .0 PROJEKTETS GENNEMF $\varnothing$ RELSE}

4.1 Unders $\phi$ gelsesområdet

\subsubsection{Beliggenhed Og Tilrådighedstående Data}

De geologiske informationer, som er bearbejdet $i$ projektets fase 1 og 2, kommer fra boringer udfort $i$ et rektangulært område $i$ Jylland. Lokaliteterne Varde, Nissum Fjord, Viborg og Vejle udg $\phi r$ hjфrnerne af rektanglet (fig.1).

På figuren er angivet de kortblade i 1:100.000 og 1:50.000 som dækker undersфgelsesområdet. Med grå raster er vist de målebordsblade $(1: 20.000)$, hvor indenfor der er gennemf $\phi r t$ systematiske boringer efter brunkul. Målebordsbladene er samlet $i$ atlasblade (1:40.000), der er nummereret efter DGU's nummersystem

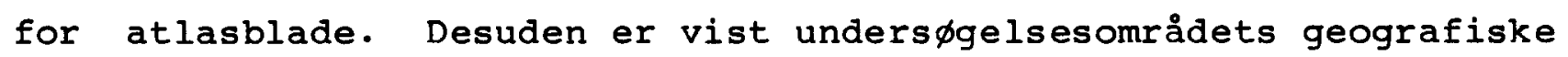
placering i Jylland.

De systematiske boringer efter brunkul er gennemfort i 1921, under og efter 2. verdenskrig samt i perioden 1958-63.

Om udf $\phi$ relsen af boringerne $i$ III kampagne skriver E.Heller (1959) p.477 følgende: "-Ved tidligere unders $\phi$ gelser dykkede man ned $i$ områder, hvor det var overvejende sandsynligt, at man ville finde brunkul. $V i$ er gået fuldstændig systematisk til værks." - og fortsætter - "Programmet er $i$ korthed følgende: Der bliver foretaget dybe boringer ned til 60 meter og 100 meter $i$ et stormasket net med $4 \mathrm{~km}$ mellem hver boring. Hvert kvadrat fyldes ud med boringer til 20 meters dybde med $1 \mathrm{~km}$ 's afstand, og bliver der $i$ kvadratet konstateret brunkul, borer vi med 250 meters mellemrum i varierende dybde".

K.Milthers, $1941 \mathrm{~s} .102$ beretter om boringerne i II brunkulskampagne

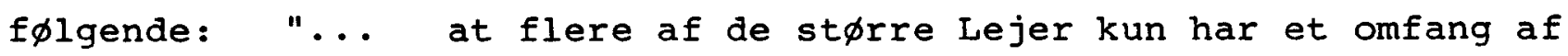
500×300 Meter; og hvis man derfor borer efter et Kvadratnet, maa Afstanden mellem Boringerne højest være 250 Meter, for at man kan være nogenlunde sikker paa at faa alle betydelige Forekomster med." Generelle informationer om boringerne er skematiseret i fig. 2 .

I fase 1 er der generelt arbejdet med atlasblade (1:40.000) og 
målebordsblade $(1: 20.000)$. I fase 2 er materialet relateret til de tidsvarende 2 og $4-\mathrm{cm}$ (1:50.000 og $1: 25.000)$.

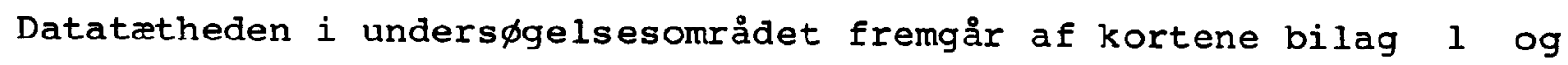
2. En boring repræsenteres på kortet af en sort prik. Kun $i$ få områder er afstanden mellem boringerne mere end $1 \mathrm{~km}$. De tætliggende boringer (afstand ned til 250 meter) koncentrerer sig $i$ hovedsagen $i$ et $c a .25 \mathrm{~km}$ bredt $\mathrm{NW}-s \varnothing$ gående bælte. Indenfor dette område er også de fleste brunkulsførende arealer samlet. Nord og syd herfor er forekomster af brunkul mere spredte og mængdemæsigt mindre.

Området dækkes af 25 atlasblade (1:40.000) nummeret efter DGU's atlasbladsnummersystem, 6 kortblade $i$ 1:100.000, 11 kortblade $i$ $1: 50.000 \mathrm{og}$ endelig 36 kortblade $i$ 1:25.000. Unders $\phi$ gelsesområdet omfatter ialt 5.100 kvardratkilometer.

Det endelige antal boringer behandlet $i$ fase 2 er 11.616 . I fase 1 var et anslået antal private boringer angivet til ca. 3.500 . Disse boringer er gennemgået $i$ fase 2, hvor antallet er opgjort til 2.500. Boringerne indgår ikke $i$ databanken, idet gennemgangen har vist at informationer, om lokalisering, kote og lagfølge, er for ufuldstændige.

\subsubsection{Geologi}

Takket være en række videnskabelige afhandlinger, eksisterer der et godt kendskab til de geologiske forhold i Midt-og Vestjylland ( se litteraturoversigten).

I unders $\phi$ gelsesområdet findes et relativt tyndt - generelt 10-15 meter - dække af istidslag (kvartære aflejringer) over de tertiære dannelser, hvori aflejringer af brunkul forekommer.

Tænkes de kvartære aflejringer fjernet, fremkommer overfladen af Danmarks undergrund (fig. 3 ).

Undergrundeslagene bliver generelt ældre fra syd mod nord $i$

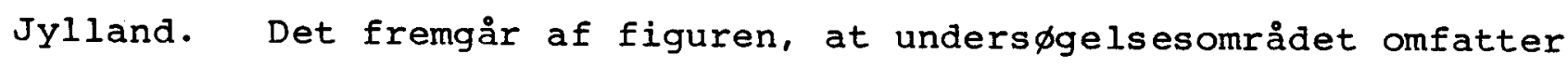


en væsentlig del af de miocæne aflejringers udbredelse $i$ Jylland. $I$ et $\phi$ st-vest vendt profil gennem Jylland vil de miocæne aflejringer $i$ vest domineres af havaflejringer (marine dannelser), mens den $\phi$ stlige del $i$ hovedsagen opbygges af landaflejringer (kontinentale aflejringer). Det er $i$ disse kontinentale aflejringer at brunkulslagene forekommer. Aflejringerne opbygges af kvartssand, glimmersand, glimmersilt samt glimmerler og $i$ forbindelse med brunkulslagene, lerlag med $h \phi j t$ organisk indhold.

De danske miocæne aflejringer repræsenterer et samspil mellem nordsфområdets havaflejringer og et delta, som har bredt sig fra фst mod vest og derved opbygget landaflejringerne. Det er $i$ overgangszonen mellem land og hav at brunkullene er dannet.

Betragtes aflejringerne $i$ Danmark under en større synsvinkel, indgår de som en del af et større og vidt udbredt deltaområde. Fra det Skandinaviske grundfjeldsomrade har floderne transporteret materiale $i$ sydlig og vestlig retning for at nå lavt liggende

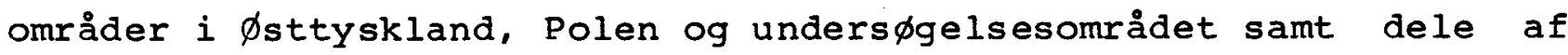
det område, der $i$ dag er dækket af Nordsфen (fig.4). Figuren illustrerer områdets maksimale udbredelse.

Et nutidigt område af lignende art som $i$ miocæn epoken $i$ Danmark, er Mississippi-deltaets udforming langs kysten af USA $i$ den nordlige del af den Mexikanske Gulf.

Efter flere års grundigt videnskabeligt arbejde, er den geologiske model velkendt $i$ det tidligere så vigtige brunkulsområde

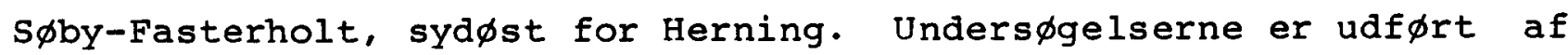
afdelingsleder lektor B. Eske Kock m.fl. ved Geologisk Institut, Århus Universitet.

Med DGU's nuværende unders $\phi g e l s e$ af de danske brunkulsreserver, underbygges den hidtil kendte geologiske model statistisk.

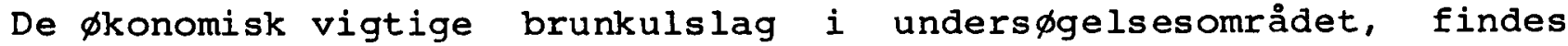
gennemgående ned til en dybde af maksimalt $24 \mathrm{~m}$. Brunkullet forekommer $i$ et eller to, sjældnere tre lag, med en samlet tykkelse på op til gennemsnitligt 2 meter. Brunkulslagene ligger generelt $i$ en samlet zone nær jordoverfladen jvf. afs. 4.2.1.4.

Fra det geologiske arbejde med profiler, er det gennemgående indtryk, at der er en udpræget parallelitet, mellem forlobet af det 
brunkulsf $\phi$ rendeintervals overgrænse og laggrænsen mellem kvartæret og tertiæret. Det er imidlertid ikke unders $\phi g t$ n $\phi j e r e, ~ i d e t$ arbejdet $i$ projektet alene tager sigte på en kortlægning og en opgørelse af Danmarks brunkulsreserver.

Brunkullene består af dødt plantemateriale og er omdannet t $\phi r v$.

Tфrv opbygges af fint fordelte plantematerialer, mosser, blade 0 . lign., større og mindre grene og endelig $i$ sjældnere tilfælde af hele stammer og stubbe.

Sumpe, sфer og moser er en nфdvenđig forudsætning for tørvedannelsen. Samtidig med en stigende grundvandsstand sker der en ophobning af plantemateriale. Når det d申de plantemateriale kommer under vand, beskyttes det mod en alt for hastig forradnelse. Det giver anledning til store ophobninger af torv, som det kendes $i$ Jylland fra Store og Lille Vildmose.

Det er dog langtfra alle tørv der omdannes til kul. En lang række betingelser skal være til stede. Først og fremmest skal tørvene beskyttes mod en evt. senere forrådnelse ved at de dækkes af sedimenter (aflejringer af ler, sand m.m., de omtalte deltaaflejringer). I den senere omdannelse, den såkaldte indkulningsproces, skal tørvene påvirkes af passende tryk og temperaturer, for at omdannelsen lidt efter lidt kan ske, forst til brunkul og senere til stenkul. Indkulningsprocessen har en varighed på adskillige millioner år.

I tørv og organisk rige aflejringer spiller svovlbakterier en særlig rolle ved at reducere sulfater til svovl. De muligg $\phi r$ dannelsen af mineralet pyrit, som er hyppigt forekommende $i$ brunkullet og dets sidebjergarter. Pyrit er en kemisk forbindelse mellem grundstofferne svovl og jern. En forudsætning for at dannelses processen forlфber, er en tilstrakkelig tilførsel af svovl og jern. Svovlet stammer fra plante- og dyreproteiner, eller tilf $\varnothing r e s$ fra andre områder som jernsulfater, via vandl $\phi b$ og/eller havvand.

Den miocæne epoke er indledt for ca. $23 \mathrm{mill}$. år tilbage og er afsluttet for ca. $5 \mathrm{mill}$. år siden. Brunkullene $i$ Danmark er dannet $i$ dette tidsrum for ca. $15 \mathrm{mill}$. år siden. 
Betragtes oversigtskortene (bilag 1 og 2) n申jere, fremtræder en "liniation" eller "retning" $i$ brunkulsområdernes beliggenhed. Den retning som træder tydeligst frem er $N W-s \varnothing$ gående. En retning som er velkendt $i$ andre sammenhænge $i$ Danmarks geologi. Noget svagere giver en N-S retning sig tilkende på kortet.

At liniationen ytrer sig ved en kortlægning af brunkulsforekomster, skyldes den omstændighed, at den tertiære lagserie og dermed brunkullene, er svagt foldet. Årsagen til foldningen er bevægelser $i$ undergrunden, langs $\mathrm{NW}-S \phi$ og $\mathrm{N}-\mathrm{S}$ gående forkastniger. De nævnte retninger er velkendte fra unders $\phi g e l s e r$ af undergrunden $i$ den $\phi v r i g e$ del af Nordeuropa.

Den geologiske bearbejdelse af de systematiske brunkulsboringer, har ikke været så indgående, at forholdene omkring brunkulslagseriens påvirkning af bevægelser $i$ undergrunden, er gennemgået nфjere.

\subsection{Arbejdsfor $1 \phi b$}

Ved starten 1. februar 1982 af brunkulsprojektets anden fase, forelå der, som resultat af arbejdet $i$ projektets fase 1 , administrative data og lagdata, indlagt $i$ en edb-styret databank for de systematiske brunkulsboringer. Standard edbprogrammer var anvendt til plotning af profiler, mængdeberegninger og endelig udtegning af et kort i 1:200.000 over Midt-og Vestjylland med angivelse af brunkulsf $\phi r e n d e$ områder.

I foråret og forsommeren 1982 samledes de informationer og erfaringer sammen, som var gjort under forlobet af fase 1 , for nфjere at tilrettelægge arbejdet $i$ fase 2. Den kontrol og justering af boringernes administrative data og lagdata, som blev foretaget mod slutningen af fase 1 fortsattes $i$ fase 2 . Arbejdet har været fortsat projektet igennem frem til midten af 1983 .

Med starten på efteråret 1982 ansattes en halvtids edb-programm $\phi r$ og arbejdet med fremstilling af programmer til lфsning af diverse opgaver, omkring den videre behandling af brunkulsboringerne, kunne begynde. 
Optagelse af data ved digitalisering indledtes $i$ slutningen af 1982 og var færdigbearbejdet mod slutningen af 2. kvartal af 1983 .

I samme periode blev der, dels forberedt ændringer af standard programmerne, som var anvendt under fase 1, dels udtegnet en række kort til brug ved den geologiske gennemgang af materialet. I perioden fra midten af 1982 og til slutningen af sommeren 1983, forl $\phi b$ den geologiske vurdering af de indsamlede data, mens udtegningen af de endelige kort og procedure til beregning af brunkulsreserven blev fastlagt $i$ perioden 4 . kvartal 1983 til 1 . kvartal 1984. I samme periode er den afsluttende rapport udarbejdet og færdigskrevet med udgangen af maj måned 1984 .

Til stфtte $i$ styringen af projektet og til orientering af medarbejdere samt andre interesserede, er udarbejdet månedsrapporter og halvårlige statusrapporter. Den 6. december

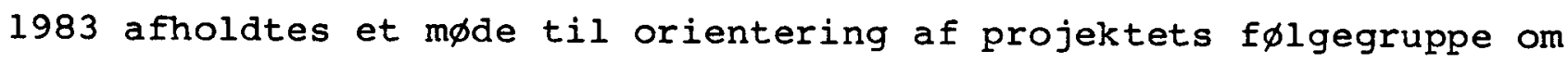
forlфbet af fase 2 .

\subsubsection{Behandling Og Tilblivelse Af Data}

\subsubsection{Digitalisering (diskrete Data)}

Fra starten af projektets anden fase, har det været hensigten, at finde en metode til kontrol af den edb-beregnede brunkulsreserve.

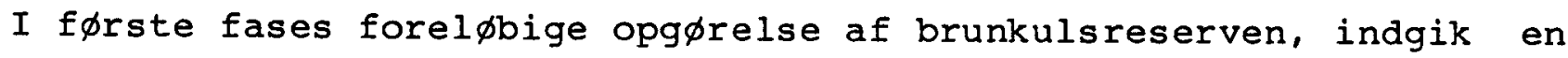
talstørrelse for den hidtil indvundne mængde brunkul. Produktionsopg $\varnothing$ relser og anslåede produktionsmængder, er lфbende registreret ved DGU på basis af indberetninger fra producenterne. Registreringen udg $\phi r$ det bedst mulige grundlag for at vurdere, hvor store brunkulsmængder, der $i$ tidens $1 \phi b$ er fjernet fra under-

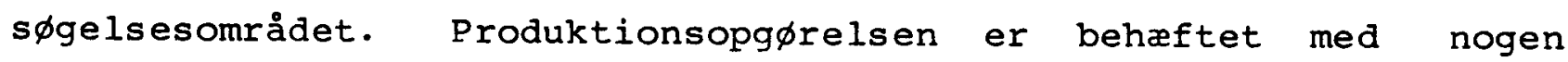
usikkerhed, men er dog det bedste udtryk, som eksisterer, for den hidtil indvundne mængde brunkul.

Til krontrol af de beregnede brunkulsmængder, har mængdeberegningsprodeduren været anvendt til også at beregne mængden af brunkul 
indenfor de hidtil omgravede arealer. Den beregnede mængden af brunkul i de gamle brunkulsgrave er derpå sammenlignet med den hidtil kendte indvundne brunkulsmængde (se afs. 5.5).

Fastlæggelsen af omgravede arealer har inddraget arkiverede optegnelser fra feltobservationer. Oplysningerne er gennemgået og indtegnet på kort. De nyeste flyfotos og kortblade over områderne, er gennemgået, for at fremskaffe det fuldstændigste billede af de gamle brunkulsgraves placering $i$ landskabet. Gravenes konturer er registreret med koordinater på digitaliseringsbord og edb-lagret.

Sidelфbende med registreringen af brunkulsgrave er foretaget en

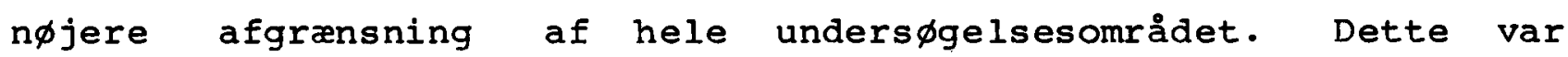
foretaget under fase 1 , men $i$ en grovere målestok end det er hensigten at udarbejde kortmateriale $i$ fase 2 .

Afgrænsningen tjener desuden det formål at være grænse for, hvortil programmellet for mængdeberegning kalkulerer mængden af brunkul.

\subsubsection{Kort Og Profiler}

Der er $i$ projektet opstillet en procedure for edb-udtegning af forskellige korttyper. Ved projektets afslutning vil samtlige kort i 1:50.000 indenfor unders $\phi$ gelsesområdet kunne udtegnes efter denne procedure.

På basis af UTM-koordinater er kort fremstillet med angivelse af boringernes geografiske placering. Placeringen er manuelt kontrolleret med en række arkiverede kortblade, som Ringkjфbing Amtskommune har anvendt ved koordinatsætningen af boringerne. Kortene er udfort i målestoksforholdene 1:20.000 og 1:40.000.

Efter kontrol af boringernes korrekte koordinater, er kort udtegnet i 1:50.000 og 1:25.000 med angivelse af, hvilke boringer der er med brunkul og hvilke der er uden. Kortene har dannet baggrund for en manuel fastlæggelse af brunkulsområder til vejledning $i$ vurderingen af den senere maskinkonturering af brunkulsførende områder. Kortene har samtidig dannet grundlag for placeringen af profiler til brug $i$ den geologiske vurdering. 
Efter fremstillingen af hvad der kan betegnes som grundkort, er udarbejdet programmel til specialudtegninger. Disse udtegninger og kontureringer kan fremstilles udfra en datasamling, som omtales nærmere $i$ efterf $\phi$ lgende afsnit om data $i$ tabelformat.

Kortene i 1:50.000, som præsenteres $i$ denne rapport, er en konturering af en summeret kultykkelse. Imidlertid kan på given foranledning fremstilles kort med konturering af dækbjergartens tykkelse, variationen $i$ tykkelsen af brunkulsintervallet og graveindex.

Kortet 1214 IV (bilag 3 -Brunkulsforekomster (u. graveindex)) er fremstillet for at give et eksempel på den korttype i 1:50.000, som kan fremstilles efter at projektet er afsluttet.

Kortet er fotografisk fremstillet, som en samkopiering af fem forskellig planer: Geodætisk Instituts liniærplan (veje og huse), plan med område afgrænsningen, plan med brunkulsgrave, plan med tekst og endelig den konturerede brunkulstykkelse. Begrundelsen for denne fremstillingsform er at flere oplysninger d.v.s. flere planer kan lægges sammen eller udskiftes til fordel for andre oplysninger. Ved denne metode vil man eksempelvis kunne samkopiere brunkulstykkelsen og overjordstykkelsen.

Bilag 4 (Brunkulsforekomster (m. graveindex)) viser 1214 IV $i$ en anden samkopiering. Efter anvendelse af graveindex, er atter udtegnet tykkelser for brunkulsmængden. Kontureringen af denne mængde har $i$ samkopieringen erstattet kontureringen af brunkulsmængden $i$ bilag 3 (om graveindex se afs. 4.2.1.3).

Desuden er fremstillet to oversigtskort i 1:200.000 bilag 1 og 2 . Kortene omtales $i$ afsnittene $4.1 .1,4.1 .2$ og 5.0 . 


\subsubsection{Boredata I Tabelformat}

For at kunne vurdere og fastlægge tilstedeværelsen af brunkul som energiråstof, er udarbejdet en tabel med oplysninger om lagf den enkelte boring. Med udgangspunkt $i$ figur 5 (skematiseret boring) er udarbejdet en tabel. I tabellen indgår oplysninger om dækbjergartens tykkelse (D), tykkelsen af det brunkulsforende interval (BKI), et tal for den summerede lagtykkelse af kul (K) $i$ $B K I$, et tal for den summerede lagtykkelse af ikke kullag (nK) $i$ BKI og endelig nogle beregnede værdier for forholdet mellem de næunte tal. I tabellen indgår en beregnet størrelse - (D+nK)/K - som betegnes graveindex. Indexet er et tal for summen af $D$ og $n K$ sat $i$ forhold til den aktuelle kulmængde $K i$ en boring. I den summerede brunkulsmængde indgår brunkulslag på $0.2 \mathrm{~m}$ og derover.

Ved siden af oplysninger om lagforholdene findes tillige opf $\phi \mathrm{rt}$ administrative data for hver boring. De administrative data er DGUnr., UTM-koordinater og kote for toppen af boringen $i$ terræn.

Oplysningerne $i$ tabellen indgår direkte $i$ profiludtegningen (de administrative data), i kontureringen og $i$ mængdeberegningen. Det er på den måde muligt at konturere enhver af sфjlerne i tabelsamlingen.

Tabellens oplysninger kan desuden anvendes med stor fordel, hvis der skal skabes et hurtigt overblik over brunkulsforekomsters størrelse og udbredelse $i$ et mindre område uden anvendelse af edb-teknik og borejournaler.

\subsubsection{Statistik For Tabeldata}

På baggrund af oplysningerne $i$ tabeldata er foretaget en statistisk bearbejdelse af værdierne for dækbjergarten (D), tykkelsen af brunkulsintervallet (BKI), antallet af brunkulslag (BKL), den summerede kultykkelse (K) og graveindexet.

På figurerne $6,7,8,9$ og 10 er vist den procentuelle fordeling af 
værdierne. Ud af samtlige boringer er 16.6 pct. brunkulsf $\phi$ rende svarende til 1929 boringer.

Variationen $i$ tykkelsen af $D$ er vist med fig. 6. Det fremgår, at $i$ over 40 pct. af de brunkulsførende boringer er dækbjergartens mægtighed 9-15 meter, mens knapt 90 pct. af boringerne har en đækbjergartstykkelse på 0-18 meter.

Tykkelsen af det brunkulsf $\phi$ rende interval (BKI) er $i \quad 68$ pct. af tilfældene på 0-2 meter og $i 23$ pct. fra 2-6 meter, d.v.s. at der $i$ godt 90 pct. er en tykkelse på 0-6 meter. Summen af dækbjergarten og brunkulsintervallet, opnår således maksimalt en tykkelse på 24 meter $i$ de systematiske brunkulsboringer. Det skal dog sammenholdes med fordelingen $i$ antallet af boringer og dybden for boringerne som vist $i$ fig. 2. Af oversigten fremgår det at den overvejende del af boringerne, ca. 10.000, er boret til en dybde af 15 og 20 meter, mens kun ca. 2700 boringer er boret dybere end 20 meter. Teoretisk kan det statistiske billede tænkes ændret, hvis samtlige boringer var boret til dybder på 30 meter eller mere. Imidlertid er der overenstemelse mellem de statistiske resultater og den geologiske viden om brunkullenes lejringsforhold jvf. det geologiske afsnit.

Figurerne 8 og 9 angiver dels antallet af brunkulslag og dels den summerede brunkulstykkelse i boringerne. I 93 pct. af boringerne er der 1-2 brunkulslag, mens den overvejende del, ca. 73 pct., er brunkulsf $\phi r e n d e$ med 1 lag. Variationen $i$ den summerede kultykkelse er for 91 pct.'s vedkommende, $i$ intervallet $0-3.0$ meter og 80 pct. $i$ intervallet $0-2.0$ meter. I ca. 30 pct. af tilfældene er brunkulstykkelsen på maksimalt 0.5 meter.

Udtrykket for graveværdigheden - graveindexet - varierer $i$ godt 50 pct. af boringerne $i$ intervallet fra 0-12. Dette betyder at over halvdelen af de brunkulsf $\phi$ rende boringer, har et indhold af brunkul $i$ en dybde, som er bedre end eller lig med 12:1, d.v.s. 12 meter overjord og 1 meter brunkul. I ca. 16 pct. af boringerne er graveindexet mellem 12 og 24 mens den $\phi v r i g e$ del er over 24 . 


\subsubsection{Kemidata}

I dette afsnit omtales data, som er tilvejebragt for beskrivelse af brunkullenes kemiske egenskaber. Analyserne er udført på materiale fra III brunkulskampagne $i$ årene 1958-63.

Der foreligger analyser for ca. 450 lag svarende til ca. 250 boringer. I betragtning af, at analyserne er udf $\phi r t$ på arkiveret materiale, er vandprocent $i$ prøverne ikke beregnet. Analyserne omfatter askeindhold, effektive brændværdi, brændværdi for brændbart stof alene samt svovlprocenten.

For at sætte III kampangnes analyseresultater $i$ relief, er de sammenlignet med resultatet af et stort antal analyser fra II brunkulskampagne $i$ perioden 1944-52. Oplysningerne stammer fra en artikel af laboratorieforstander, civilingeniфr Th. Mogensen. Artiklen er trykt i Hedeselskabets Tidsskrift nr. 6, 74. årg. 1953. Analyserne er udført på grundlag af de prфver, der er indsendt af statens daværende brunkulstilsyn. Prфverne er udtaget af friskopgravede brunkul eller i selve brunkulslejerne og udg $\phi r$ over 90 pct. af samtlige udtagne brunkulsprøver i II brunkulskampagne.

Fig. 11 viser fordelingen af antal analyser, $i$ relation til effektive brændværdi, for prфver fra III brunkulskampagne. Der er foretaget en inddeling $i$ klasser på $100 \mathrm{kcal} / \mathrm{kg} \mathrm{pr}$. klasse, lфbende fra 900 til $3200 \mathrm{kcal} / \mathrm{kg}$. I hver klasse er udregnet en gennemsnits askeprocent på vandfrit materiale. $P a ̊$ figuren er angivet talværdien for askeprocenten $i$ de enkelte klasser sammen med punkternes regressionsline. Korrelationskoefficienten for askeværdierne er på 0.993. Spredningen af askeværdierne omkring gennemsnittet er således meget lille.

Regressionslinien, for askeværdier omregnet til prover med 50 pct. vand, er indtegnet på figuren. Det gælder for regressionslinierne, at de repræsenterer den lovmæssighed, der er $i$ sammenhængen mellem askeindhold og effektive brændværdi, $i$ denne sammenhæng danske brunkul $i$ frisk opgravet tilstand. Med stigende indhold af aske $i$ brunkullet falder den effektive brændværdi.

Fremtidige analyser af brunkulslag vil kunne gennemf $\phi$ res enkelt, idet blot askeprocenten $i$ proverne bestemmes. Den sandsynlige 
effektive brændværdi kan da aflæses af figur 11. Eksempelvis må en prфve med et askeindhold på 15 pct. forventes at have en effektiv brændværdi på ca. 2000-2100 kcal/kg .

Begrundelsen for valget af 50 pct. vandindhold fremgår af figur 12. Figuren er fremstiliet efter Mogensen (1953) og omfatter 13035 analyser. Vandprocenten er afsat som abcisse og procentfordelingen som ordinat. Det ses af kurven, at der er et udpræget maksimum ved 49 pct. vandindhold, idet ca. 90 pct. ligger mellem 44 og 54 pct. vand. Der er derfor god grund til at antage, at fremtidige analyser af friskopgravede brunkul vil have et vandindhold på ca. 50 pct.

Ved afbrænding af en brændselsenhed vil vandindholdet forbruge en stor del af den varmeenergi, som det brændbare materiale udvikler. Da forbrændingstemperaturen ligger langt over vands kogepunkt, vil der medgå stor varmeenergi til fordampning af den vandmængde en brændselsenhed indeholder.

For at reducere vandindholdet kunne de frisk opgravede brunkul lufttфrres på stedet inden en videre transport til forbrændingsstedet. Herom skriver imidlertid Milther,K (1944) p.187 - "Inden brunkullene leveres, skal de lagres $i 14$ dage, for at vandindholdet, som normalt ligger på ca. 50 pct., kan nedsættes lidt. Der er dog kun faa procent, der derved forsvinder."

I vurderingen af kuls kvalitet har askeprocenten væsentlig betydning. Det organiske materiale må afgive varme til det ikke organiske materiale (asken), for at bringe temperaturen på dette op på forbrændingsvarmen. Når forbrændingsprocessen er overstået, afkфles asken ved varmestråling til omgivelserne. Et lavt askeindhold $i$ kul er ensbetydende med god kvalitet. Jo lavere askeindholdet er, jo mere brugbar energi leveres der ved forbrændingsprocessen, dels fordi en mindre mængde aske skal opvarmes, dels fordi mængden af brændbart materiale pr. vægtenhed er st $\phi r r e$.

På figur 13 er udtegnet askeværdierne for analyser fra II brunkulskampagne (13035 prфver) sammen med analyser foretaget på materialer fra III brunkulskampagne (450 prфver).

Askeindholdet $i$ prфverne fra II kampagne - "er beregnet med det 
vandindhold brunkulsprфverne havde ved modtagelsen $i$ laboratoriet, d.v.s. ved det vandindhold som brunkullenen har $i$ lejet eller $i$ friskopgravet tilstand". Af kurven fremgår det, at den hyppigste askeprocent ligger mellem 4 og 8 pct. og har et markant maksimum på ca. 5 pct.

Kurven for analyser på materiale fra III kampagne er noget fladere, men viser dog et maksimum omkring 11 pct., med den væsentligste del af analyserne $i$ intervallet 6-16 pct. Analyserne er foretaget på tørret materiale, hvorfor askeprocenten, for sammenligneligheden er omregnet til 50 pct. vandindhold (fig. 11).

Forskydningen $i$ de to kurver skyldes, at de brunkul som blev opgravet $i$ 40-erne, var af en bedre kvalitet. I lavninger hvor akkumulationen af brunkul har været stor, har tilforslen af mineroget materiale (aske-materiale) været lav og derfor givet kul af en god kvalitet.

De brunkulsforekomster, som er påvist i III brunkulskampagne, er af ringere kvalitet. Torveophobningen har fundet sted $i$ perifere områder, set $i$ relation til de gode brunkulsområder. Herom skriver E.Heller (1959) p.446 følgende: "-Det kan ikke nægtes, at kvaliteten gennemgående er noget ringere end under den anden kampagne, hvor man forb $\phi d$ brydning af brunkul med et varmeindhold under 1950 kalorier".

Den effektive nyttige brændværdi af et brændsel, er den varmemængde, som udvikles af en vægtenhed af materialet ved en fuldstændig forbrænding $i$ et lukket rum med et ilt tryk på 20-30 kg pr. kvadratcentimeter (Dansk standard). I materialet er askeindhold og fugtighed som $i$ en friskopgravet pr $\phi v e$.

For sammenlignelighedens skyld er der $i$ fig 14, hvor den effektive brændværdi er afbildet på abcissen og fordelingsprocenten på ordinaten, bevaret nogle skæve klasseinddelinger fra 1800 til 3200 $\mathrm{kcal} / \mathrm{kg}$. Baggrunden herfor er, at man $i$ 40-erne inddelte brunkulskvaliteten $i$ klasser af varmeenheder. Hver klasse modsvaredes da af et vist kronebel $\phi \mathrm{b}$ pr. $\mathrm{kg}$ brændsel, til udregning af betalingen for den brunkulsmængde, som blev handlet.

Det fremgår af figuren, at III kampagnes kurveforl $\phi b$ har stor overenstemmelse med II kampagnes. Imidlertid skal kurven for III kampagne forskydes mod lavere brændværdi med ca. $250 \mathrm{kcal}$. Der er 
i fremstillingen ikke taget hensyn til at, den effektive brændværdi i II kampagne er beregnet på basis af ca. 50 pct. vandindhold, mens III kampagnes brændværdier er omregnet til 45 pct. fugtighed. Fordampningen af den for den effektive brændværdi med ca. $250 \mathrm{kcal}$. Forskydningen betyder

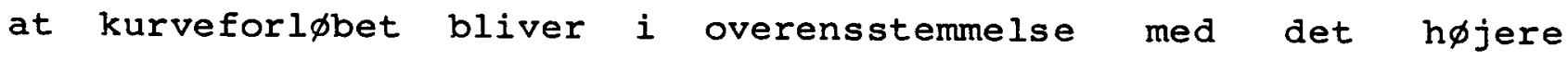
askeindhold, som vist med figur 13. H $\phi$ jere askeindhold resulterer $i$ lavere effektiv brændværdi. Flytningen af kurven ændrer imidlertid ikke det generelle billede for fordelingen af den effektive brændværdi.

Det fremgår af begge kurveforl $\phi b$, at der er et maximum for den nyttige brændværdi, når den omtalte kurveforskydning tages $i$ betragtning, i intervallet $2000-2700 \mathrm{kcal} / \mathrm{kg}$. Den overvejende del af analyserne falder indenfor intervallet fra $1800-3200 \mathrm{kcal} / \mathrm{kg}$.

Kurvens lokale maximum $i$ intervallet $1600-1800 \mathrm{kcal} / \mathrm{kg} \mathrm{sky}$ des dels

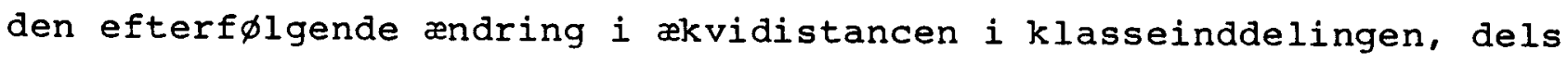
den omstændighed, at der er foretaget en selektion $i$ udvælgelsen af prфver, der ved feltiagttagelse kan opfattes som brunkul.

I en række tilfælde er udvalgt en bestemt bjergartstype, som har været antaget for brunkul. Ved laboratorieunders $\phi$ gelse har bjergartens brændværdi samlet sig om en bestemt brændværdi.

Det er en bjergart med et så tilpas indhold af organisk materiale, at den har kunnet antages for brunkul. Brunkulslagenes sidebjergarter repræsenteres ofte ved en glidende overgang med stigende organiske indhold fra lerlag til brunkulslag.

Af figur 11 fremgår det, at askeprocenten for disse lag ligger omkring 18-24 pct., når der ses på intervallet 1400-1800 kcal/kg for den effektivebrændværdi. Når det tages $i$ betragtning, at der er et vandindhold på ca. 50 pct., vil indholdet af organisk materiale være på ca. 25 pct. I egentlige brunkulslag ligger det organiske indhold på ca. 40 til 50 pct., med en effektiv brændværdi på omkring $2500 \mathrm{kcal} / \mathrm{kg}$. For stenkul/antracit ligger brændværdien på ca. 6000-8000 kcal/kg.

Variationen $i$ brændværdien af selve det brændbare stof er vist $i$ figur 15. Brændværdien af brændbart stof er et entydigt udtryk for kulkvaliteten, når denne ses $i$ sammenhæng med indkulningsgraden (omaannelsen af det organiske materiale $i$ retning af stenkul og antracit). For brunkullene ligger brændværdien $i$ området fra 
6000-6700 kcal, mens brændværdien for stenkul/antracit ligger to til tre gange hфjere.

For beskrivelsen af svovlmængden $i$ de analyserede prover er fremstillet figur 16. Prøverne fra II kampagne udviser et udpræget maksimum for svovlindholdet $i$ intervallet 3.0-3.5 pct., idet ca. 30 pct. af prøverne ligger $i$ dette interval. Svovlprocenten for den overvejende del af analyserne - ca. 70 pct. - falder $i$ intervallet 2.5 til 4.0 pct.

Analyseresultaterne for III kampagne viser god overensstemmelse med resultaterne fra II kampagne, selv om maksimum ligger lidt forskudt.

I analyserne indgår sidebjergarterne til brunkulslagene. Disse lag udviser en svovlprocent som afviger meget lidt fra svovlprocenten $i$ brunkuls lagene.

Sammenfattende viser analyserne fra II og III brunkulskampagne, at de danske brunkulsforekomster har et vandindhold på 44-54 pct., med et askeindhold på 4-8 pct. når kullene er bedst, og for dårligere forekomster fra 6 pct. til 16 pct. Den effektive nyttige brændværdi, ligger fra ca. $1800 \mathrm{til} 3000 \mathrm{kcal} / \mathrm{kg}$, med den hyppigste brændværdi på 2000-2700 kcal/kg. Brændværdien af det brændbare stof alene ligger $i$ intervallet fra $6000-6600 \mathrm{kcal} / \mathrm{kg}$. Indholdet af svovl er mellem $2.5 \mathrm{og} 4.0$ pct.

\subsubsection{EDB-programmer}

Ved projektets start 1980 forelå en stor del af de generelle standard programmer, som skulle anvendes $i$ projektet. I l $\phi$ bet af projektet er disse programmer ændret og udbygget $i$ st $\phi r r e$ eller mindre grad alt efter de forhåndenværende problemer. Desuden er helt nye programmer udviklet.

De nyudviklede programmer varetager indlægning, opdatering, retning og sletning af data, $i$ den fra begyndelsen oprettede brunkulsdatabank. Herfra kan udtegnes data med henblik på 
udtegning af profiler. Et standard profilprogram er ændret, så der $i$ profilerne bl.a. gives en særlig markering for brunkulslag og for registreret kvartær/tertiær grænse. Det er en hjælp ved korrelationsabejdet, at brunkulslagene er fremhævet i profilplotningen. For konverteringen og samk $\phi$ ring af henholdsvis lagdata og administrative data, er udviklet en række mindre programmer, som alene har interesse under tildannelse af profiler.

Kortet, som udtegnedes ved afslutningen af fase 1 , blev til på baggrund af anvendelsen af et standard korttegningsprogrammel. I fase 2 har dette program ikke været anvendt. Derimod er anvendt to programpakker indk $\phi b t$ af DGU. Det ene betegnes SURFACE II og har været anvendt til udtegning af korteksempel $i$ 1:50.000, mens det andet, UNIRAS har været anvendt til udtegning og farvelægning af oversigtskort i 1:200.000. Begge korttegningssystemer er tilpasset projektets behov på visse væsentlige punkter. SURFACE II har desuden været anvendt til at danne de matricer, som mængdeberegningen er foretaget udfra.

Ved fremstillingen af farvekonturplot med UNIRAS, er der benyttet en interpolationsmetode, som kombinerer linie-, kvadratisk-og afstandsvægtning.

Boringerne er først sorteret $i$ et kvadratisk gridnet. Herefter er der interpoleret til de grid, der ikke indeholder nogen værdi. Der er ved interpolationen benyttet et gridnet på 200 x 200 punkter og en sфgeafstand på 1000 meter.

Det skal dog bemærkes, at ved denne interpolationsmetode er der fare for at nogle af de interpolerede grid ligger over maksimumseller under minimumsværdierne for de kendte gridpunkter.

Princippet i SURFACE II er, at der ned over det unders $\phi$ gte område lægges et gridnet (har 210 x 260 punkter). Alle hj申rnerne $i$ nettet sфges nu tildelt en værdi v.h.a. interpolation ud fra punktinformationerne (boringerne). Det fremkomne resultat er en matrice, som $i$ dette tilfælde indeholder værdier med brunkulstykkelsen eller en kode for manglende information.

Interpolationen foregår ved at man, til hvert gridhjorne, finder de fire nærmeste boringer og vægter dem $i$ forhold til hinanden. Ved vægtningen tages hensyn til kultykkelsen og afstanden fra hver boring til gridhjørnet. Boringens vægt formindskes med kvardratet på afstanden. Hvis der ikke er mindst en boring indenfor 500 
meters afstand, og fire boringer indenfor 1000 meters afstand fra et gridhjørne, tildeles dette kodeværdien "manglende information". Tallene 4, 500 og 1000 kan vælges frit, og er valgt udfra et geologisk sk $\phi$ n og efter afpr $\varnothing v n i n g$ med forskellige værdier.

Sammen med kontureringen af brunkulsforekomster, er indtegnet omrids af brunkulsgravede områder. Til udtegning af grave og afgrænsning af området, er anvendt et DGU programmel betegnet ZETA.

ZETA er et generelt, interaktivt kartografisk edb-system, som bl.a. kan bruges til udtegning af temakort. I dette tilfælde er ZETA alene anvendt til udtegning af målfaste kort over brunkulsgrave og unders $\phi g e$ ls esområdets afgrænsning.

Korttegningsprogrammerne arbejder alle på data fra et register, som er dannet udfra databanken, v.h.a. nyudviklet programmel. I registret indgår DGUnr., UTM-koordinater, kote og en række typiske parametre for beskrivelse af brunkullenes forekomst $i$ jorden (se afsnit $4 \cdot 2 \cdot 1 \cdot 3)$.

Desuden er nogle delvis korrigerede programmer anvendt til optagelse og behandling af relative koordinater. Programmellet konverterer korthjфrners relative bordkordinater til UTM-koordinater, under hensyntagen til eventuelle divergenser mellem de omregnede UTM-koordinater og Geodætisk Instituts UTM-koordinater for kortbladshjфrnerne. Foruden korthjфrner er de relative koordinater for afgrænsningen af undersфgelsesomradet og omrids af brunkulsgrave omregnet til UTM-koordinater under anvendelse af det omtalte programmel.

\subsection{RESULTATER}

I projektets anden fase er - $i$ farver - produceret to oversigtskort (bilag 1 og 2) $i$ målestoksforholdet 1:200.000. Det ene kort viser, hvor der forekommer brunkul i Midt-og Vestjylland, det andet en klasse inddeling af graveindexet i samme område.

På kortene kan man oversigtligt orientere sig ved de storre byers tilstedeværelse, landeveje og amtsgrænser samt UTM-koordinater. 
Datatætheden - tætheden af boringer - fremgår af tætheden af sorte prikker på kortene, idet en boring repræsenteres af en sort prik.

Ved siden af disse to kort, fremlægges desuden to detailkortblade $i$ 1:50.000 (bilag 3 og 4) af 1214 IV. Kortene er et eksempel på hvad projektets edb-programmer og en efterfølgende fotografisk samkopiering, kan fremstille af kort.

Bilag 3 (brunkulsforekomster (u. graveindex)) viser konturerede brunkulsforekomster på baggrund af en geologisk bearbejdet datasamling over summerede kultykkelser. På kortet er indtegnet

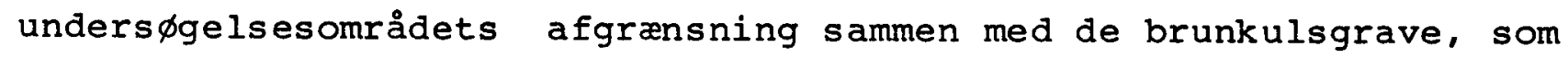
$i$ projektets fase 2 er registreret indenfor kortbladet. Kortet angiver således de brunkulsområder som endnu ikke er omgravet.

Bilag 4 (brunkulsforekomster (m. graveindex)) er samme kortblad som bilag 3. På dette kortblad er imidlertid kontureret den summerede tykkelse for forekomster af brunkul, der har et graveindex på 12 og derunder. Brunkulsgrave og områdets afgrænsning er fortsat angivet. For den nøjere orienterings skyld, er der som baggrund indlagt Geodætisk Instituts liniærplan for kortbladet.

I forbindelse med kontureringen, er foretaget en beregning af brunkulsmængden indenfor kortbladet, dels den mængde som findes når alt medregnes, dels mængden under hensyntagen til graveindex. I begge tilfalde er der samtidig foretaget en beregning af brunkulsmængden $i$ de omgravede områder (gamle brunkulsgrave).

Der er foretaget en sådan beregning for samtlige de $2-\mathrm{cm}$ kort som omfatter de systematisk gennemborede arealer (tabel 1 ).

\subsection{Brunkulsmængden - Samlede Oprindelige}

Tabel 1 giver en oversigt over de mængdeberegninger som er udf $\phi$ rt. Brunkulsmængden totalt pr. kortblad i 1:50.000 varierer fra mindre end 1 mill. kubikmeter og op til $58 \mathrm{mill}$. kubikmeter. De st $\phi$ rste mængder koncentrerer sig $i$ den centrale del af området på 1114 I-II og 1214 III-IV med mere end 80 pct. af de samlede totale 
brunkulsmængder. Nord, syd og vest herfor varierer mængden fra mindre end $1 \mathrm{mill}$. kubikmeter til knapt $9 \mathrm{mill}$. kubikmeter.

Området indeholder samlet 176 mill. kubikmeter, der omregnet svarer til $126 \mathrm{mill}$. tons. Omregningsfaktor er 1.4 jvf. Miljфministeriets bekendtgфrelse nr. 364 af 17 juli 1978 .

\subsection{Brunkulsmængden - Indvundet}

Den indvundne brunkulsmængde har frem til 1958, været opgjort til ca. $32 \mathrm{mill}$. tons. Tallene stammer fra indberetninger til DGU om produktion og om forbrug på forbrændingsstedet. Hertil kommer et forbrug fra 1958 til 1971 på ca $4 \mathrm{mill}$. tons, en forbrugt total brunkulsmængde på ca. $36 \mathrm{mill}$. tons svarende til ca. $50 \mathrm{mill}$. kubikmeter.

Af tabel 1 fremgår det, at der er edb-beregnet en mængde, for de registrerede brunkulsgrave $i$ hele området, på ca. 38 mill. kubikmeter brunkul.

\subsection{Brunkulsreserven}

For hvert kortblad (tabel 1) er beregnet en brunkulsmængde under hensyntagen til et graveindex (ang. graveindex se afs. 4.2.1.3). Ved opgфrelsen af brunkulsreserven, er valgt grænseværdien 12 i graveindex. Brunkulsf $\phi r e n d e$ boringer med graveindex mindre end eller lig 12, indgår $i$ beregningen af brunkulsreserven.

For hele området er den beregnede totale mængde brunkul ca. 127 mill. kubikmeter. Fradrages den beregnede mængde af brunkul $i$ gravene, fås en brunkulsreserve på ca. 89 mill. kubikmeter, svarende til ca. 63 mill. tons.

Under anvendelse af følgende omregningsfaktorer: 
BRUNKULSMENGDEN I MIDT- OG VESTJYLLAND

-opgjort pr. 2-cm kort.

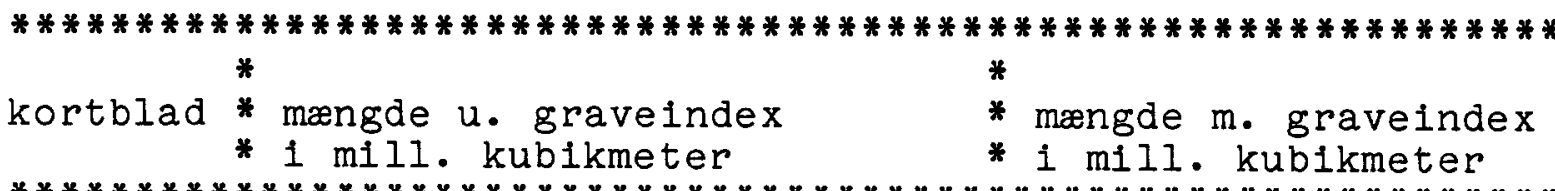

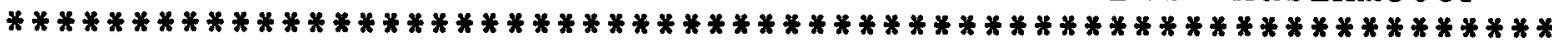

1115 III mængdetotal :<0,1 indh. 1 grave: $<0,1$

1115 II mængdetotal : 1,6 indh. i grave: 1,6

1215 III mængdetotal : 8,3 indh. i grave: 7,9

1114 IV mængdetotal : 8,8 indh. 1 grave: 8,8

1114 I mængdetotal : 46,3 indh. 1 grave: 35,5

1214 IV mængdetotal : 58,2 indh. i grave: 37,2

1114 III mængdetotal $:<0,1$ indh. i grave: $<0,1$

1114 II mængdetotal : 20,8 indh. i grave: 16,9

1214 III mængdetotal : 21,3 indh. i grave: 19,6

1113 I mængdetotal : 4,4 indh. I grave: 4,4

1213 IV mængdetotal : 6,5 indh. i grave: 6,2

Hele området :

mængdetotal : 176,2 indh. i grave: 138,1 opgravet : 38,1 mængdetotal : 0,0 indh. 1 grave: 0,0

mængdetotal : 1,1 indh. 1 grave: 1,1 mængdetotal : 5,6 indh. 1 grave: 5,2 mængdetotal 6,2 indh. 1 grave: 6,2 mængdetotal : 34,4 indh. 1 grave: 23,9 mængdetotal : 49,5 indh. 1 grave: 29,0 mængdetotal $:<0,1$ indh. i grave: $<0,1$ mængdetotal : 15,9 indh. i grave: 12,2 mængdetotal : 12,9 indh. I grave: 11,5 mængdetotal : 0,3 indh. i grave: 0,3 mængdetotal : 1,5 indh. 1 grave: 1,2

mængdetotal : 127,4 indh. i grave: 90,6 opgravet : 36,8 
- svarende til ca. $10000 \mathrm{kcal} / \mathrm{kg}$

Minimums brændværdi for brunkul

$2000 \mathrm{kcal} / \mathrm{kg}$

Maksimums brændværdi for brunkul

$2700 \mathrm{kcal} / \mathrm{kg}$

Gennemsnits brændværdi for brunkul

$2400 \mathrm{kcal} / \mathrm{kg}$

- modsvares den beregnede brunkulsreserve af 12,5-17,0 mil1. tons gasolie med en gennemsnitlig værdi på 15.0 mill.tons.

\subsection{Resultater Af Kemianalyser}

Den kemiske beskaffenhed af reserven er iflg. resultatet af de kemiske analyser (se afs. 4.2.1.4) et vandindhold på 44-54 pct., et askeindhold på 4-8 pct. når kullene er bedst og $i$ dårligere forekomster fra 6 pct. til 16 pct.

Den effektive nyttige brændværdi af brunkullene ligger fra ca. $1800 \mathrm{til} 3000 \mathrm{kcal} / \mathrm{kg}$, med den hyppigst fundne brændværdi på 2000-2700 $\mathrm{kcal} / \mathrm{kg}$. Brændværdien af det brændbare stof alene ligger $i$ intervallet fra $6000-6600 \mathrm{kcal} / \mathrm{kg}$. Indholdet af svovl varierer mellem 2.5 og 4.0 pct.

\subsection{EVALUERING AF RESULTATER}

Ved interpolationen, som danner grundlag for kortudtegningen og mængdeberegningen, er interpolations-afstanden på maksimalt 1 km, idet mindst en boring skal være indenfor en afstand på $0.5 \mathrm{~km}$. Med en større interpolationsafstand udtegnes kort med lukkede kurver for brunkulstykkelsen, mens den kortere afstand efterlader abrupt afskårne kurver mod områder uden information om tilstedevarelse af brunkul. Størrelsen af disse områder er, når de er mindst ca. 1.2 kvadratkilometer.

Den korte interpolations-afstand er valgt, fordi interpolationen danner grundlag for edb-beregningen af brunkulsreserven. Den beregnede reserve angiver den mængde, som ligger præcist indenfor kurverne. 
Dette er valgt sådan, fordi der $i$ de områder, hvor brunkul er registreret er boret tættere (ca. 250 meter) så en nogenlunde afgrænsning af en forekomst har kunnet gennemfores. Det vil derfor med denne opgфrelse af brunkulsreserven $i$ Danmark, synes urimeligt at lade "teknikken" beregne brunkulsforekomster i store områder, hvor der vides at være boret med stor afstand, fordi brunkul ikke er påvist eller forekommer $i$ uinteressante mængder, jvf. afsnit 4.1 .1 om kvadratnet.

Den samlede oprindelige brunkulsmængde er opgjort til ca. 176 mill. kubikmeter. Resultatet af de forel $\phi b i g e$ beregninger $i$ projektets forste fase gav en samlet oprindelig mængde på ca 291 mil1. kubikmeter. Mængden er reduceret med ca. 40 pct. Forklaringen herpå er de geologiske hensyn, som er indlagt i interpolations-afstanden, samt den geologiske gennemgang af selve boringerne. Disse overvejelser indgik ikke $i$ mængdeberegningen under fase 1 . Det har ved den geologiske gennemgang vist sig, at standardprogrammet fra fase 1 til tider har beregnet brunkulsforekomster, hvor der iflg. den geologiske opfattelse, ikke er brunkul.

Pålideligheden $i$ beregningen af brunkulsmængderne ses af beregningen af den allerede indvunane brunkulsmængde jvf. afs. $5.2 \circ \mathrm{og} 4.2 .1 .1$. De hidtil kendte tal for den indvundne mængde, er ca. $50 \mathrm{mill}$. kubikmeter, mens den edb-beregnede indvundne brunkulsmængde ex på ca. $38 \mathrm{mill}$. kubikmeter. Dette tal er bedre end det umiddelbart synes.

Sammenlignes kontureringen af brunkulsforekomster og beliggenheden af brunkulsgrave, $g \phi r$ to forhold sig gældende ved beregning af brunkul i de registrerede brunkulsgrave. For det første rækker de digitaliserede brunkulsgrave nogle steder udover de konturerede brunkulsmængder og vil derfor $i$ edb-beregningen af brunkulsmængden indeholde mindre brunkul end der faktisk vil være indberettet som produceret. For det andet er der bland de registrerede grave nogle, som forekommer uden for de konturerede brunkulsområder

Tallet for den beregnede indvundne brunkulsmængde vil derfor kunne for $\phi$ ges noget, og kommer herved $i$ overensstemmelse med de hidtil kendte produktionsmængder på ca. 50 mill. kubikmeter. I beregningen af brunkulsmængder og dermed reserven kan man således 
gå udfra at den anvendte interpolationsmetode beregner værdier, som er realistiske.

Åsagen til at visse brunkulsgrave ligger udenfor de konturerede områder er, at de systematiske brunkulsboringer blev gennemf $\phi r t ~ i$ områder, hvor forekomster af brunkul endnu ikke var påvist. I områder med eksisterende brunkulsgrave, har arealerne været uden interesse, alene af den grund at en grav allerede var etableret $i$ området. For at indhente ny viden on udbredelsen af brunkul, er de systematiske boringer koncentreret $i$ de dengang ukendte områder. Det skal dog understreges, at de væsentligste brunkulsgrave er sammenfaldende med de konturerede brunkulsarealer.

En sammenligning mellem de danske brunkuls kemiske forhold og brunkulsforekomster andre steder $i$ verden fremgår af fig. 17 . Her er de danske brunkuls gennemsnitlige værdier for vand- og askeindhold samt effektive brændværdi indtegnet. De danske brunkul er angivet med nr. 13 i rækken af brunkulsområder.

Brunkullene ligger $i$ tæt overensstemmelse med de områder, som traditionelt sammenlignes med danske brunkul, nemlig nr. 4 Neurath $i$ brunkulsområdet ved Kфln i Tyskland (rhinske brunkul) og nr. 6 - Turow i Polen.

Tidsmæsigt er brunkullene ved $k \phi l n$, dannet på samme tidspunkt som de danske og under tilsvarende geologiske forhold. Brunkullene har $i$ modsætning til de danske en anseelig mægtighed på 60-100 meter. Brunkullene anvendes $i$ vid udstrækning til elektricitets produktion.

Gennemsnitligt varierer vandindholdet $i$ disse brunkullene mellem 45 og 65 pct. mens askeindholdet varierer mellem 1 og 2 pct. med maksimumsværdier på ca. 5 pct. Den gennemsnitlige brændværdi på vand- og askefrit stof, varierer mellem 5600-6500 $\mathrm{kcal} / \mathrm{kg}$, med maksimumsværdier ved ca. $6100 \mathrm{kcal} / \mathrm{kg}$, mens brændværdien for friske brunkul ligger mellem $1600-3000 \mathrm{kcal} / \mathrm{kg}$ (Kothen, H. \& Reichenbach, K. 1981).

Svovlindholdet er lavt $i$ disse kul. Det ligger fra 0.2-1.0 pct.

De væsentligste forskelle mellem de rhinske brunkul og de danske, 
er indholdet af svovl og aske. I de danske brunkul er

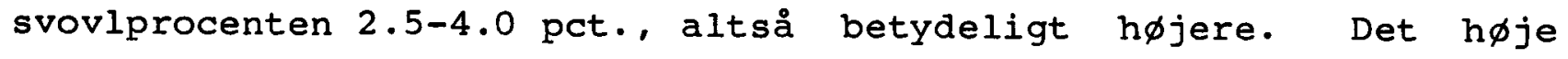
svovlindhold er, ved afbrændingen af brunkullene, en vasentlig faktor $i$ påvirkningen af miljфet.

Askeindholdet $i$ de danske brunkul er $i$ de bedste kul 4-8 pct., altså lidt højere end $i$ de rhinske brunkul, mens det for de dårligere brunkul er væsentlig højere, nemlig 6-16 pct.

De danske brunkuls brændværdi ligger på nogenlunde samme niveau, som de rhinske brunkul, men er dog af en ringere beskaffenhed p.g.a. det høje aske- og svovlindhold.

\subsection{MILJ $\varnothing$ ASPEKTER VED BRUNKULSBRYDNINGEN OG ANVENDELSEN}

Den danske brunkulsreserve udg $\not r$ - set $i$ relation til den samlede energisituation, en begrænset ressource.

Indvinding af danske brunkul har fundet sted til forskellige tider, bl.a. perioder med brændselsknaphed. Undertiden har denne brunkulsindvinding givet uheldige fфlgevirkninger for det omgivende $\operatorname{mi} 1 j \varnothing$.

Brunkulsindvindinger har eksempelvis fort til udledning af surt og okkerholdigt vand til vandlфbene, hvorved visse vandl $\phi b$ er $\phi$ delagt for dyr og planter, og andre er skadet $i$ betydelig grad. Grundvandsforurening $i$ forbindelse med brunkulsgravning kendes også. Hertil kommer gener som fllge af sandflugt fra forladte og ikke efterbehandlede brunkulsgrave.

De danske brunkul har, som det fremgår af unders $\phi g e l s e n$ i projektets anden fase, et ikke ubetydeligt indhold af svovlforbindelser. Det må derfor påregnes at afbrænding af brunkullene kan give anledning til luftforurening. Disse miljøgener kan formentlig afb $\phi d e s$ eller afværges gennem passende efterbehandlingsarbejde og ved rensning af rфggassen. For at opnå kendskab til art og omfang af eventuelle skadevirkninger på miljøet, har Miljøministeriet, Departementet, $i$ skrivelse af 20. maj 1980 til Energiministeriet, gjort opmærksom på behovet for at få gennemfort en belysning af de 
miljømæssige konsekvenser ved en eventuel indvinding og anvendelse af brunkullene.

\subsection{KONKLUSION}

Der er $i$ projektet EFP-80 og 82 Danmarks Brunkulsreserver, gennemf $\phi \mathrm{rt}$ en kortlægning og beregning af brunkulsreserven $i$ Danmark, under anvendelse af moderne edb-teknik.

Der er gennemf $\varnothing \mathrm{rt}$ en geologisk analyse af lejringsforholdene for brunkulsaflejringerne. Det har resulteret $i$ opstilling af et såkaldt graveindex, som er et mål for den tilstedeværende brunkulsmængde sat $i$ relation til den dybde, hvori brunkulsmængden forekommer. Hertil kommer resultater af en række kemiske analyser, som angiver askeprocenten, den effektive brændværdi, brændværdien for brændbart stof og svovlindholdet $i$ brunkulslagene og deres sidebjergarter.

Brunkulsreserven er opgjort til ca. $89 \mathrm{mill}$. kubikmeter, svarende til knapt det dobbelte af den hidtil kendte brunkulsreserve på ca. $50 \mathrm{mill}$. kubikmeter. Brunkullenes kemiske beskaffenhed består $i$ et vandindhold på 44-54 pct., en aske pct. på 4-16, en effektiv nytte-brændværdi på 1800-3000 $\mathrm{kcal} / \mathrm{kg}$ og endelig et svovlindhold på $2.5-4.0$ pat.

Med afslutningen af anden fase af projektet til opgørelse af Danmarks brunkulsreserver, præsenteres de n $\phi$ dvendige forudsætninger for at gennemfore en samlet vurdering af miljøgenerne ved anvendelse af brunkul som energiråstof. En sådan samlet vurdering

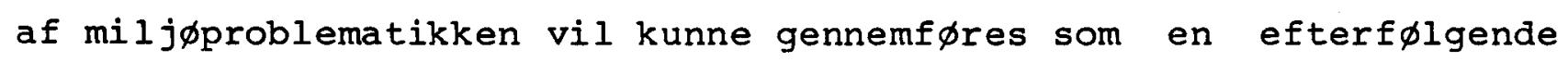
tredje fase af brunkulsprojektet. 


\subsection{AFSLUTNING}

Med afslutningen af projektets anden fase, skal der rettes en varm tak til Prof.Lic.scient. Arne Villumsen, Statsgeolog Erik Heller og Statsgeolog Henning Kristiansen, for deres støtte til projektet.

Landinspekt $\phi r$ Karl Kristensen skal takkes for vedholdende arbejde med projektets edb-problemer frem til 31.12.83, hvor han fratrådte projektet.

En særlig tak skal rettes til datalog Bjфrn Hermansen, som har ydet en indsigtsfuld og engageret indsats med udformning af kort og korttegningsprogrammel $i$ de sidste seks måneder af projektets anden fase. Han har desuden medvirket ved gennemlæsning og retning af rapporten, samt bidraget til denne med en redegørelse for funktionerne af programmerne SURFACE II og ZETA.

For tilblivelsen af oversigtskortet $i$ farver, skal programm $\phi r$ sten Aabo Hansen takkes for en hurtig og effektiv indsats. Sten Aabo Hansen har desuden bidraget til rapporten med en redegфrelse for funktionerne af DGU's programpakke UNIRAS.

For indtastningen af det store data-materiale, takkes tasteoperat $\phi r$ Zofia orlowicz for vedholdende og hurtigt arbejde.

Tegner Torben Jensen takkes for sin indsats ved tegnebordet, under udarbejdelsen af figurer og kort til rapporten.

Assistent Birgit Nielsen skal have tak for at have anvendt sine engelsk-kundskaber under tilblivelsen af det engelske resume.

Sluttelig skal assistent Lone Andreasen takkes for arbejdet ved skrivemaskine og skærmterminal. 
LITTERATUROVERSIGT:

BIJLSMA, S. 1981: Fluvial sedimentation from the Fennoscandian area into the North-West European Basin during the Late Cenozoic. In: A.J. van Loon (ed.): Quaternary geology: a farewell to A.J. Wiggers - Geol. Mijnbouw 60:337-345.

KOTHEN, K. \& Reichenbach, K 1981: Teufenabhängigkeit und gegenseltige Bezlehungen von Qualitätsparametern der Braunkohle der Niederrheinischen Bucht. -

Fortschr. Geol Rheinld. u. Westf. 29:353-380, Krefeld 1981.

SYMPOSIUM, 1979: The Continental Miocene of Central Jutland Denmark. Edt.: B.E. Koch \& E.F. Christensen. Aarhus University, June the 11th-16th, 1979.

SYMPOSIUM, 1979: Proceedings - The Continental Miocene of Central Jutland: Geology - Brown coal Facies - Stratigraphy Paleontology. EDT.: B. Eske Koch. Aarhus University June 11 th-16th, 1979.

MORRISON, G.F. 1978: Combustion of low grade Coal. Report IEA Coal Research, London 1978 .

KOCH, B.E. 1975 : Træk af brunkulsbrydningens historie i Danmark. MIV 5(museerne i Viborg amt), 1975:10-19, 1975.

KOCH, B.E. et al. 1973 : Den miocæne brunkulsflora og dens geolo-

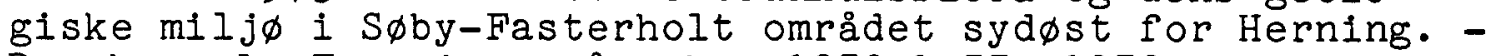
Dansk geol. Forening., Arsskr. 1972:1-57, 1972.

LARSEN, G. \& FRIIS, H. 1973 : Sedimentologiske unders $\emptyset$ gelser af det jyske ung-Tertiær. -

Meddr. dansk geol. Foren. Arsskr. 1972:119-128, 1972.

HELLER, E. 1961 : Keld Milthers arbejde med brunkulseftersфgningen. - Meddr. dansk geol. Foren. 14:447-453, 1961.

HELLER, E. 1961 : Iagttagelser over tertiære og kvartære forhold i Tarm-Brande-Grindsted-området. -

Meddr. dansk geol. Foren. $14: 37 \overline{4}-385,1961$.

RASMUSSEN, L.B. 1961: De Miocæne Formationer i Danmark. Danm. geol. Unders. rk. 4:4:5:45 pp.

HELLER, E. 1959: 165 nye brunkulsfund til en værdi af mindst $150 \mathrm{mill}$. kr. Ingeniøren $2 i: 445-448$, København 1959.

MOGENSEN, Th. 1959: Tørvebrændsels- og brunkulsproduktion 1952 belyst ved analyser. Hedeselskabets Tidsskrift nr. 6 årg. 74:85-95, 1953.

INGWERSEN, W. 1949 : Iagttagelser i de jydske Brunkulsgrave. Meddr. dansk geol. Foren. 11:486-488, 1949. 
MILTHERS, K. 1944 : Det danske Brunkulseventyr. -

Ingeniøren 53 årg. 45:K67-K69, 1944.

MILTHERS, K. 1941 : Systematisk Efters $\emptyset$ gning af Brunkul. Geogr. Tidsskr. 44:100-117, 1941.

MILTHERS, K. 1941 : De danske Brunkul og deres Udnyttelse. -

Ledetraad ved folkelig Universitetsunderv. 115:4pp, 1941

MILTHERS, K. 1939 : Kortbladet Brande. -

DGU 1:18:163pp, København 1939 


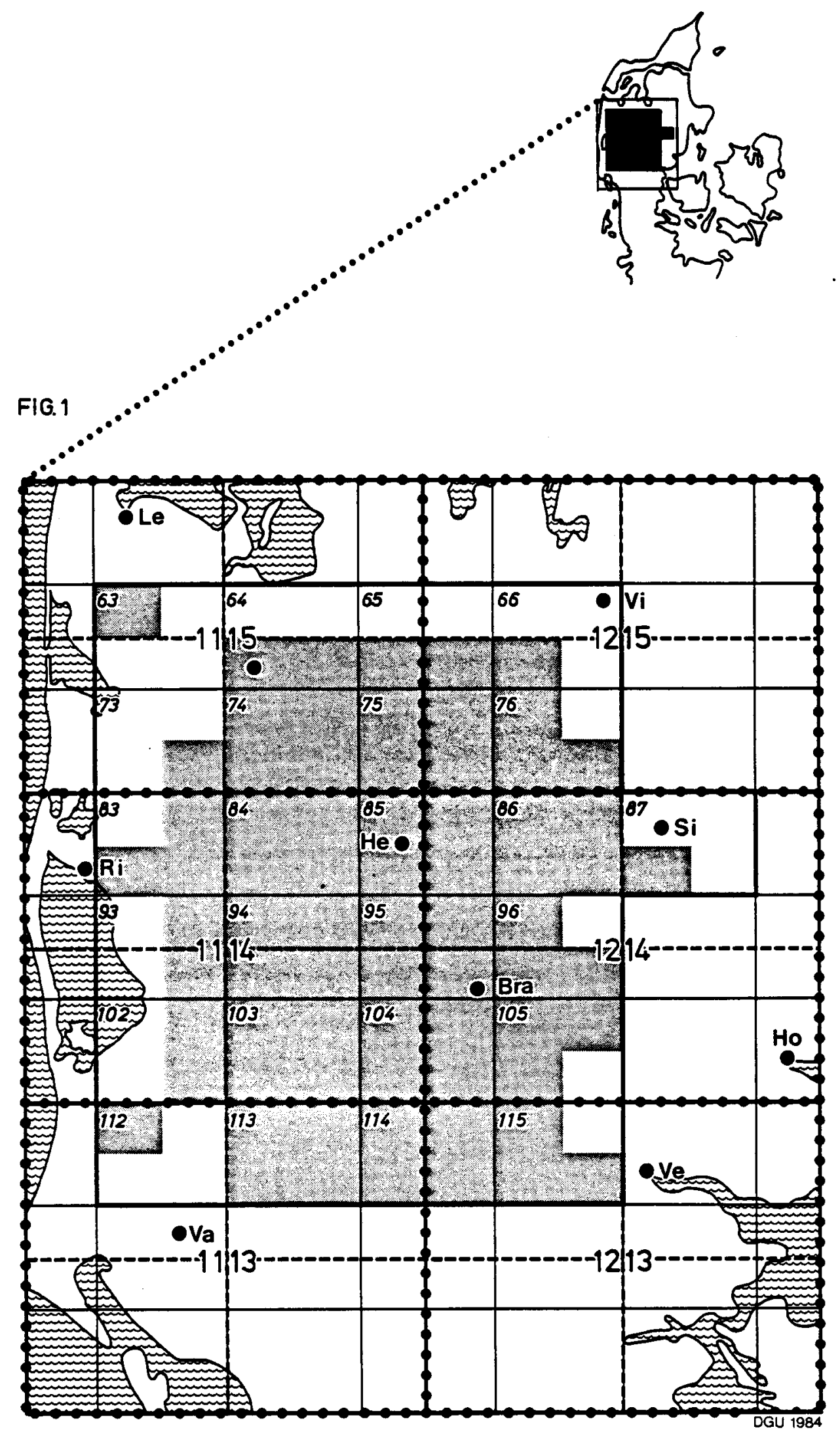

- Med raster er vist området indenfor hvilket der er gennemført systematiske boringer efter brunkul.

Omradet er inddelt $i$ en række kortblade som angivet pd figuren.

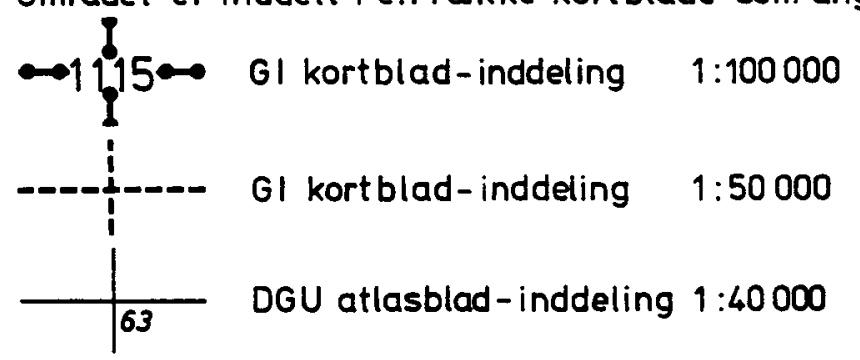


FIG. 2

\begin{tabular}{|c|c|c|c|c|}
\hline & PERIODE & $\begin{array}{l}\text { ANTAL } \\
\text { BORINGER }\end{array}$ & DYBDE & GENNEMBORET OMRADE \\
\hline 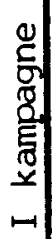 & 1921 & 629 & $\begin{array}{c}10-15 \mathrm{~m} \\
\text { og } \\
30 \mathrm{~m}\end{array}$ & $\begin{array}{l}\text { Omräderne vest for Brande d.v.s. Nr. Vium } \\
\text { Troldhede, Ahler, Sandet-Sdr. Felding, Ronum } \\
\text { Gejlbjerg - Sandfeld. }\end{array}$ \\
\hline 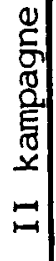 & $1941-49$ & ca. 10.000 & 15 og $20 \mathrm{~m}$ & $\begin{array}{l}\text { Egnen mellem Holstebro, Skjern og } \mathrm{Nr} \text {. Snede } \\
\text { som ikke har varet gennemboret i } 1921 \text {. }\end{array}$ \\
\hline 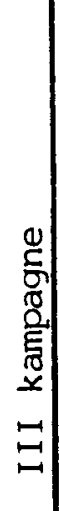 & $1958-63$ & $\begin{array}{lr}\text { ca. } & 2750 \\
& \\
& \\
\text { Heraf: } & \\
\text { ca. } & 63 \\
& 106 \\
& 1695 \\
& 278\end{array}$ & $\begin{array}{r} \\
60-100 \mathrm{~m} \\
60 \mathrm{~m} \\
25-30 \mathrm{~m} \\
15-25 \mathrm{~m}\end{array}$ & $\begin{array}{l}\text { Egnen mellem Grindsted og Holstebro som ikke } \\
\text { tidligere har været gennemboret. }\end{array}$ \\
\hline
\end{tabular}

Generelle informationer om boringerne i I, II og II brunkulskampagne. 
FIG. 3

Geologisk kort over Danmark. Formationerne ved basis af kvartæret

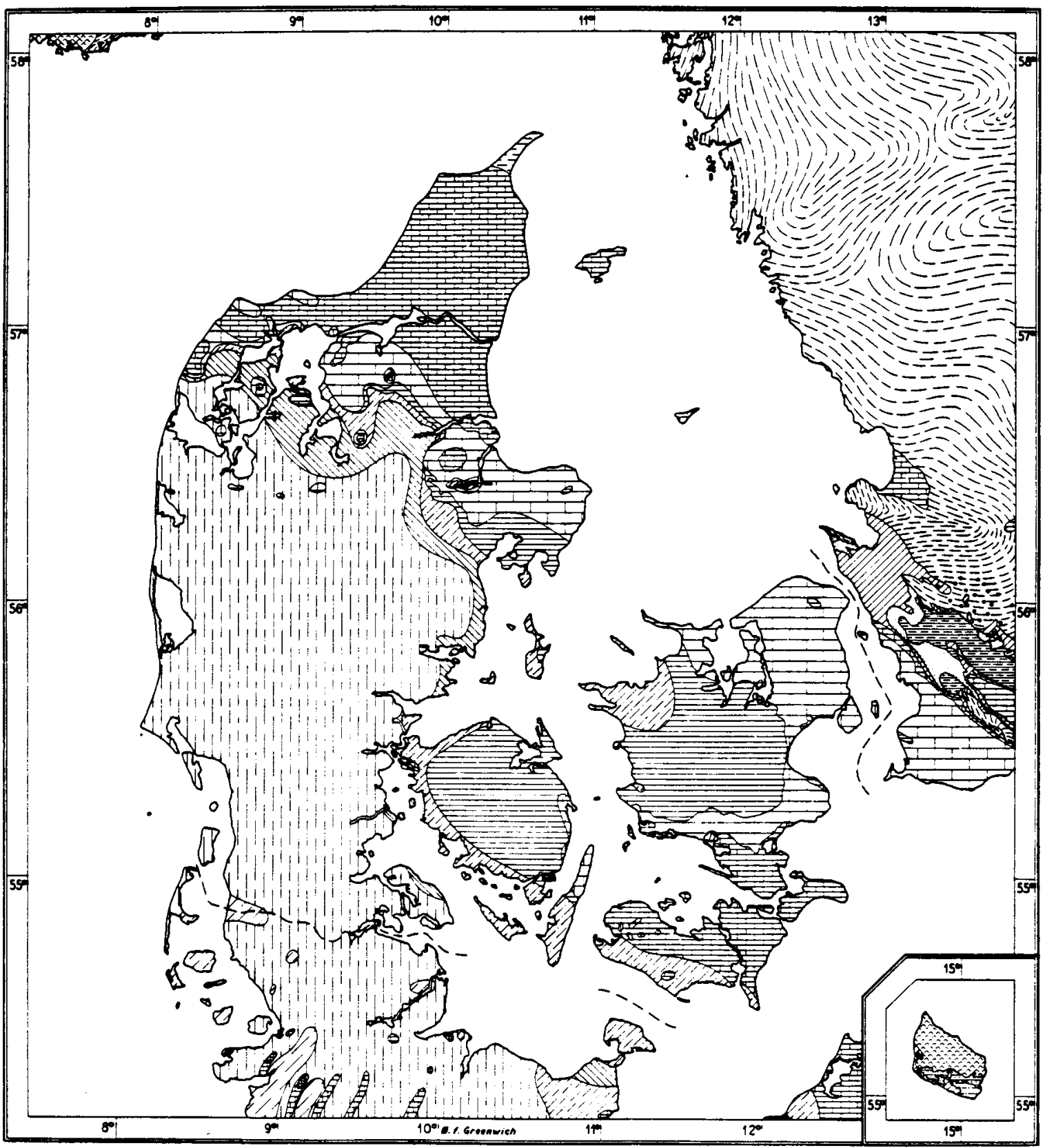

GEOLOGISK KORT OVER DANMARK. FORMATIONERNE VED BASIS AF KVARTERET.

\begin{tabular}{|c|c|c|c|c|c|}
\hline 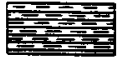 & $\begin{array}{l}\text { Gotlandium } \\
\text { og Ordovicium }\end{array}$ & E! & Danien & - & Basalt \\
\hline$=2$ & $\begin{array}{l}\text { Gotlandium, } \\
\text { Ordovicium og } \\
\text { Kombrium }\end{array}$ & W & Oure Kridt & & Pliocan \\
\hline 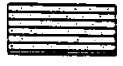 & $\begin{array}{l}\text { Kambrium } \\
\text { (Nexesandsten) }\end{array}$ & $=0$ & Nedre Kridt & 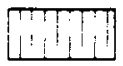 & Miocan \\
\hline 洞 & Kambrium & EDPUTत्र & Rhaet-Jura & & Oligocan \\
\hline 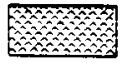 & Granit & & Trias & & Eocan \\
\hline 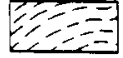 & Gnejs & W & Perm & $\equiv$ & Poleocan \\
\hline
\end{tabular}


FIG. 4

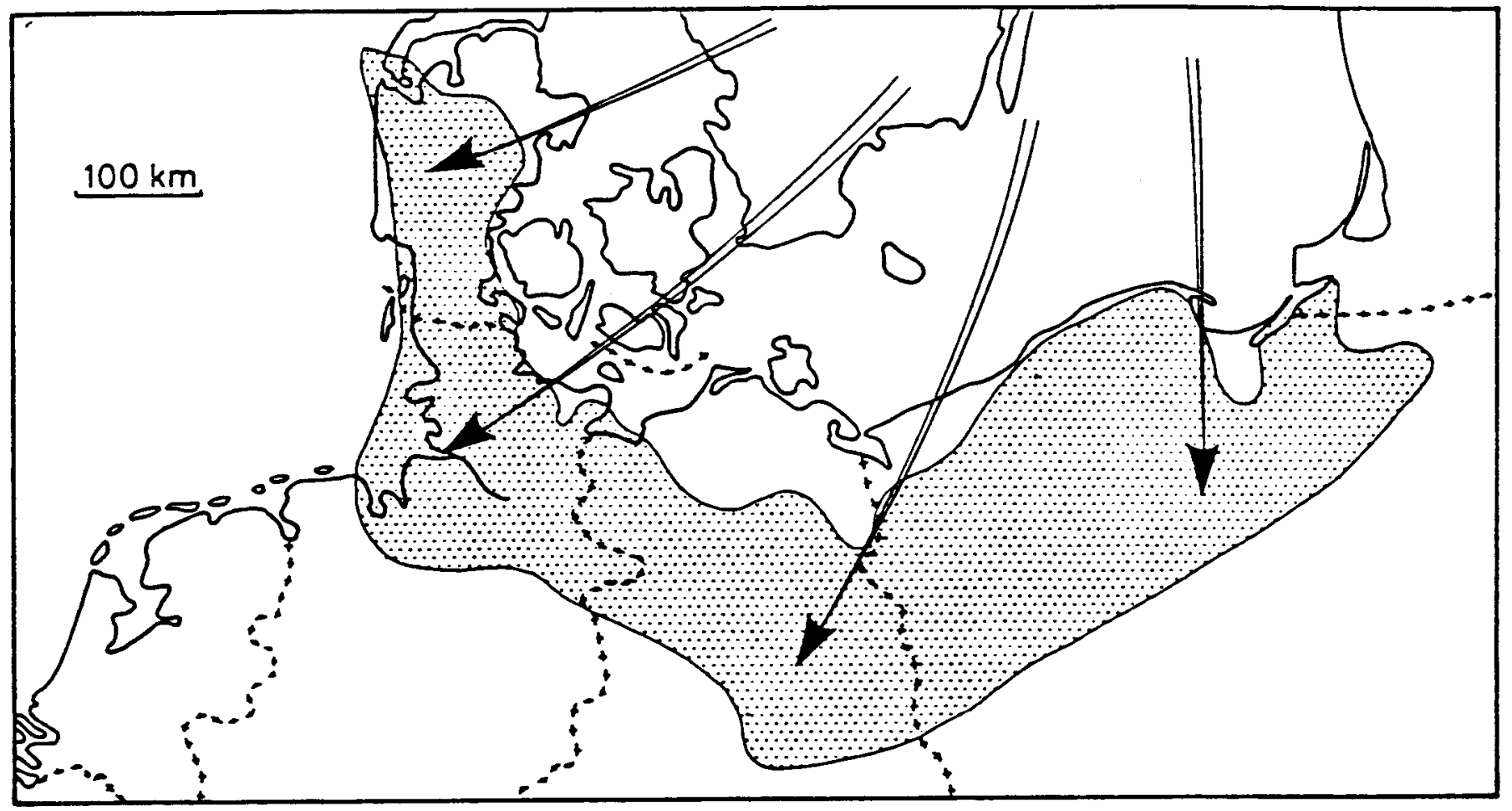

Fig. 4 - viser hvor deltasandsdannelserne forekommer og deres maximale udbredelse. Pilene angiver den formodede retning for flodernes transport af materiale. (mod. eft. Bijlsma 1981) 
FIG.5

GENERALISERET BOREPROFIL

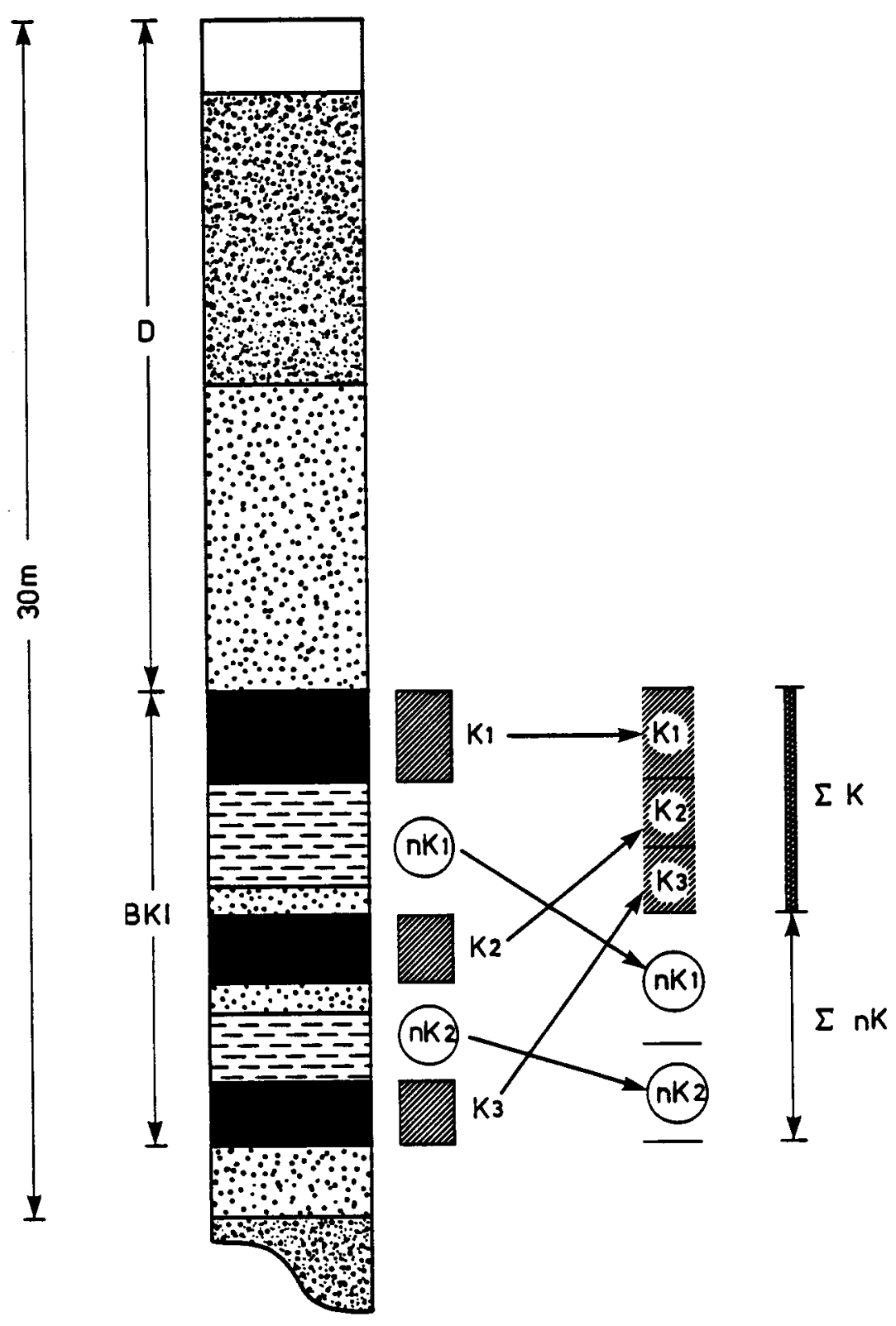

$D=$ Dokbjergart

$B K I=$ Brunkulsinterval

$K=$ Brunkulslag i BKI

$n K=$ Lag af non brunkul i BKI 
Fig. 6 Dokbjergart (D)

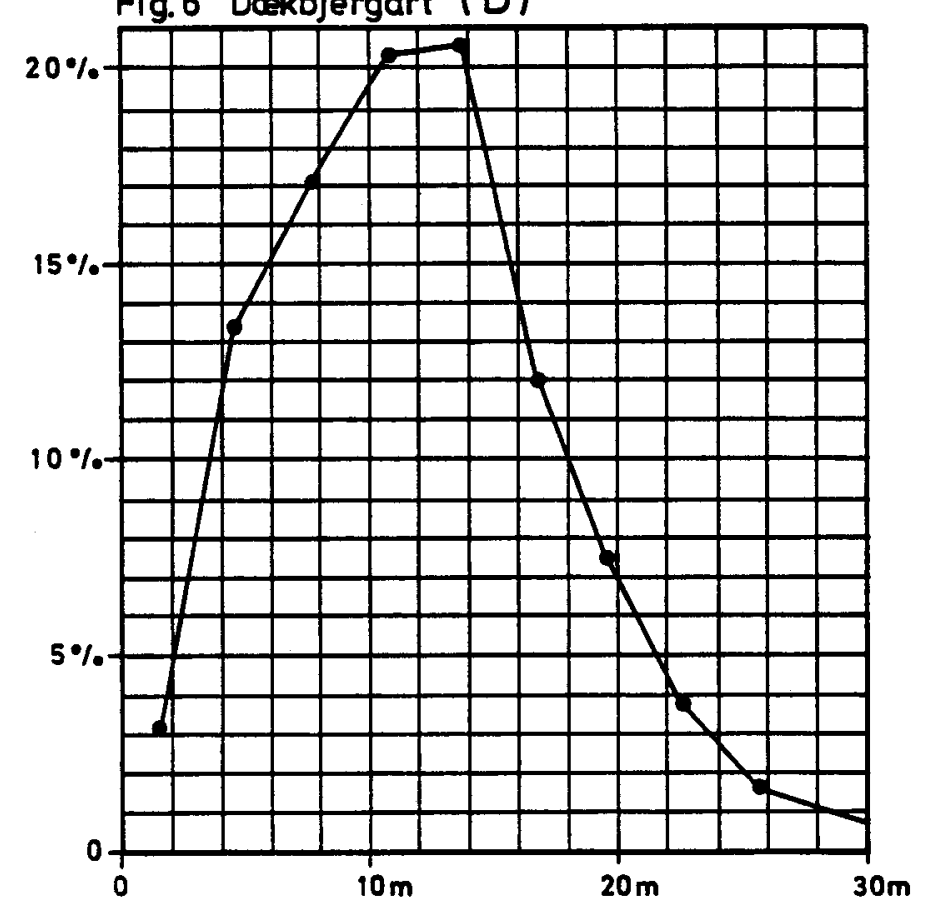

Fig.7 Brunkulsinterval (BKI)

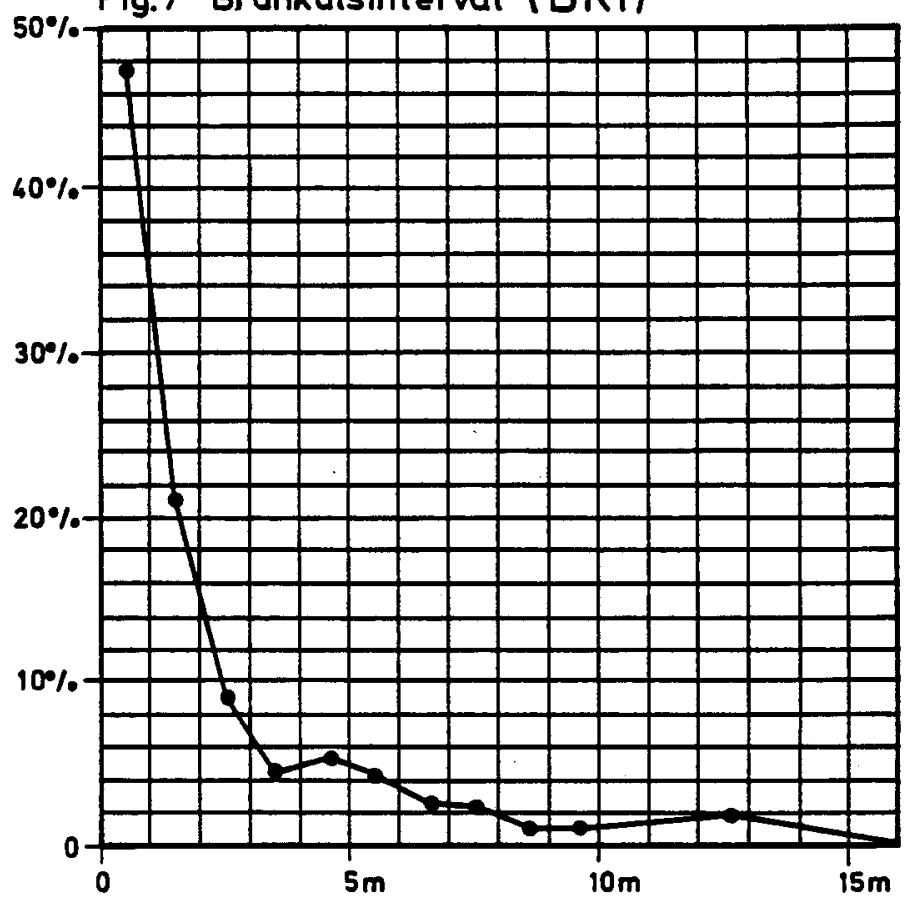

Fig. 8 Brunkulslag (BKL)

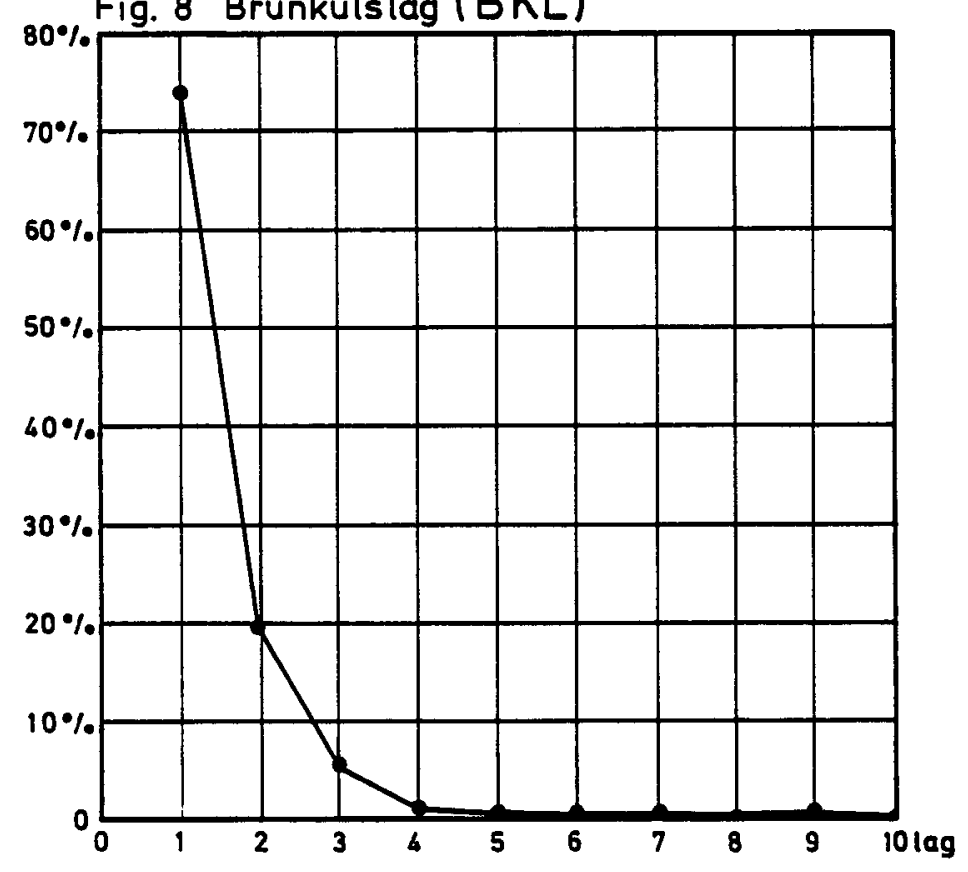

Fig. 9 Summeret kultykkelse (K)

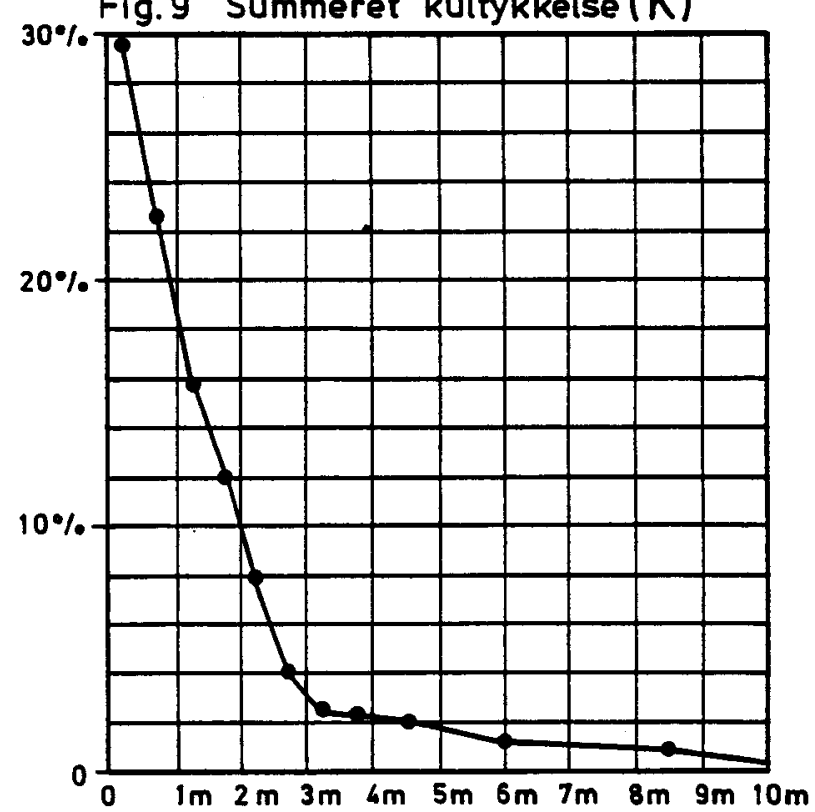

Fig. 10 Graveindex

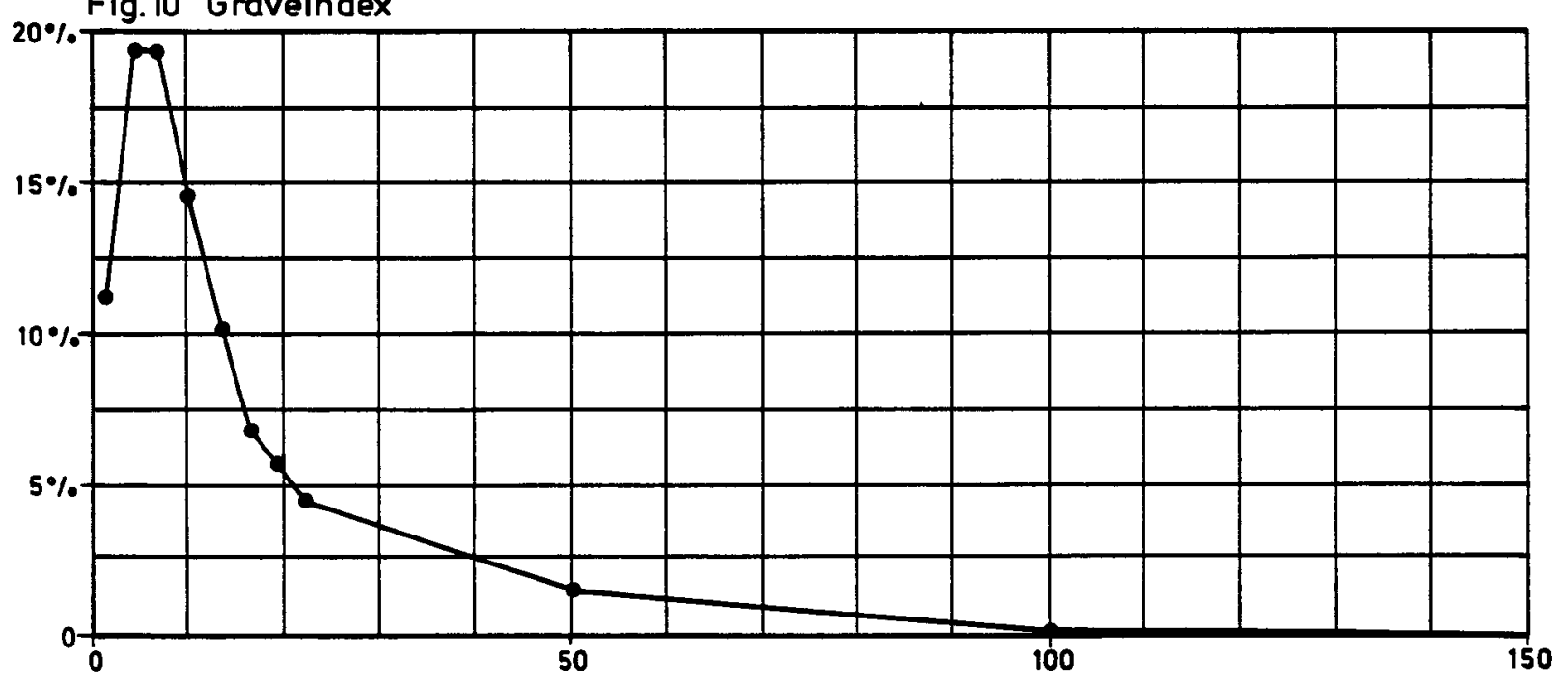


FIG. 11

KEMISKE ANALYSER OG ANTAL

PRØVER III KAMPAGNE

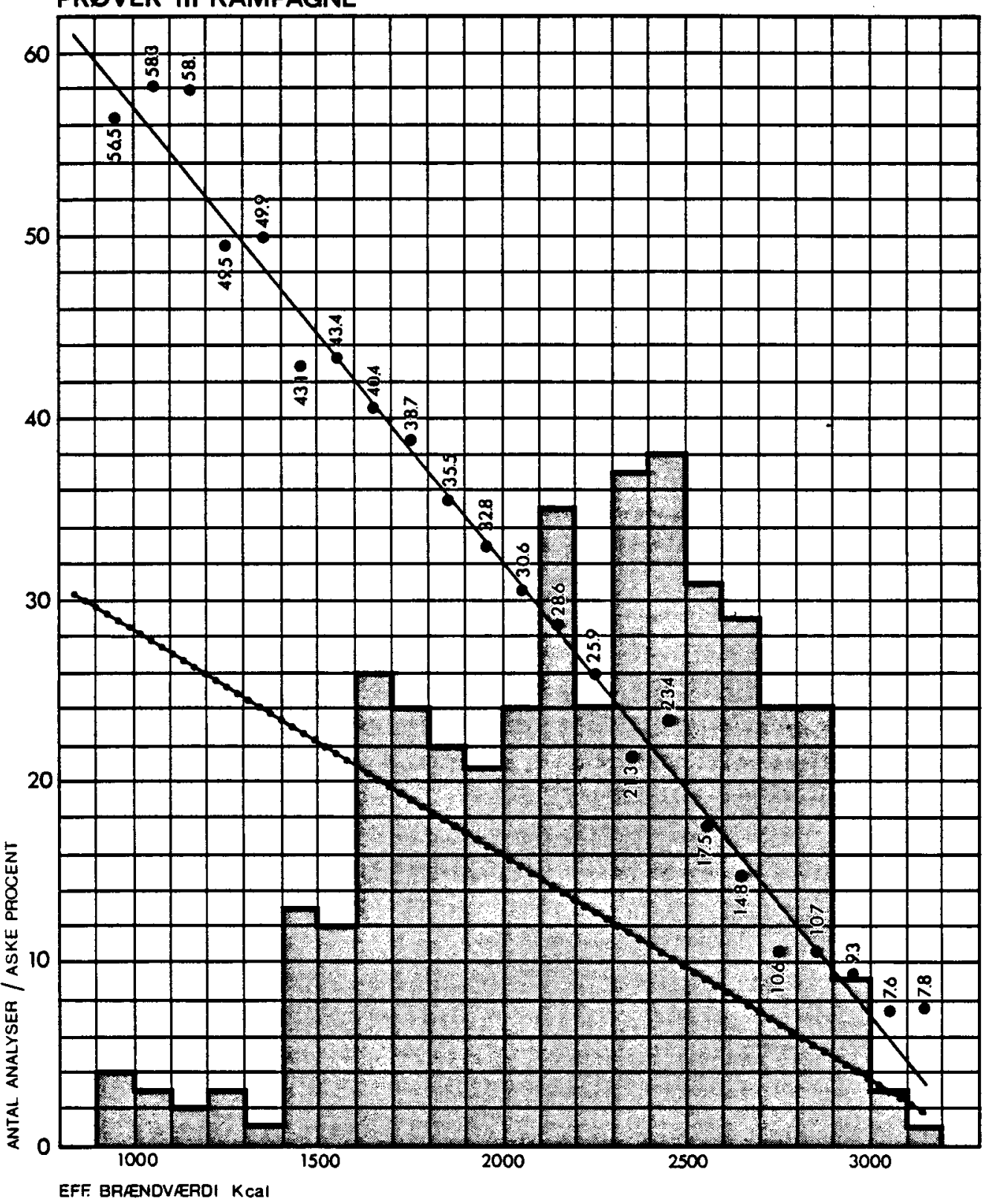

REGRESSIONSLINIE FOR ASKE\% I VANDFRIE PROVER

REGRESSIONSLINIE FOR ASKE $\%$ MED $50 \%$ VAND

ANTAL ANALYSER 
FIG. 12

HYPPIGHEDSKURVE FOR VANDPROCENTEN

PRØVER II KAMPAGNE

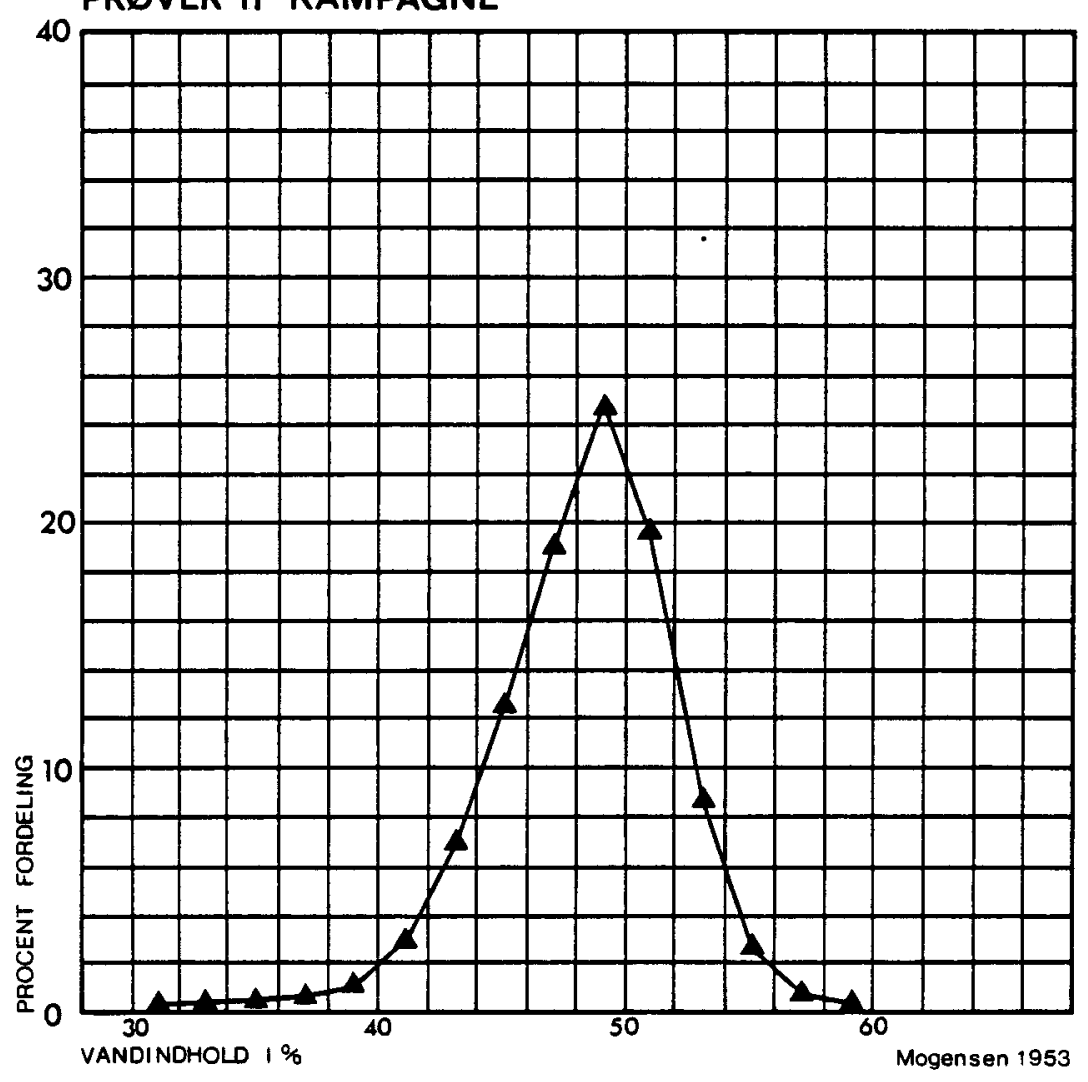




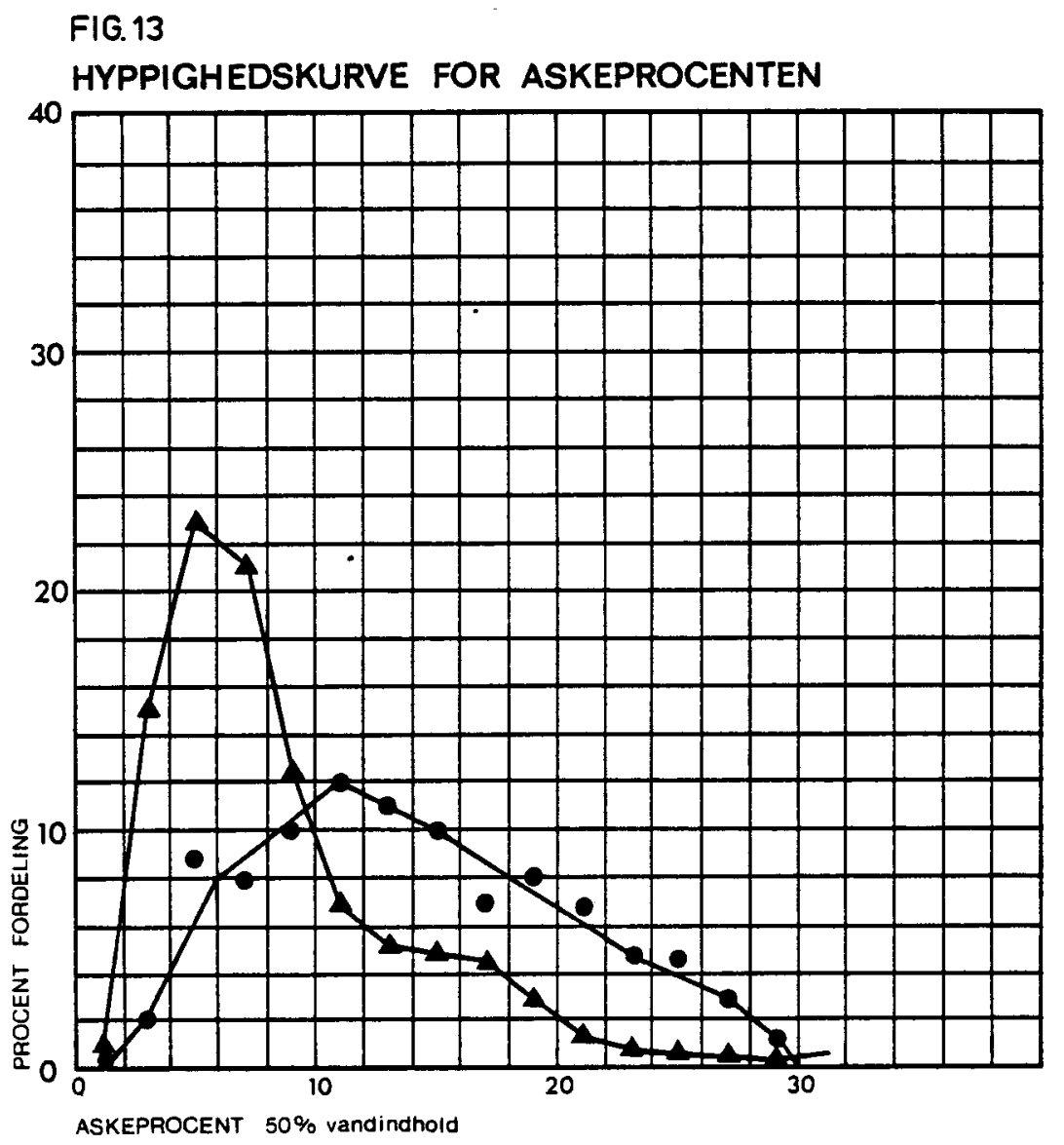

Analyser II kampagne (antal 13035) (Mogensen 1953)

Analyser III kampagne (antal 450) 
FIG.14

HYPPIGHEDSKURVE FOR EFFEKTIV BRAENDVAERDI

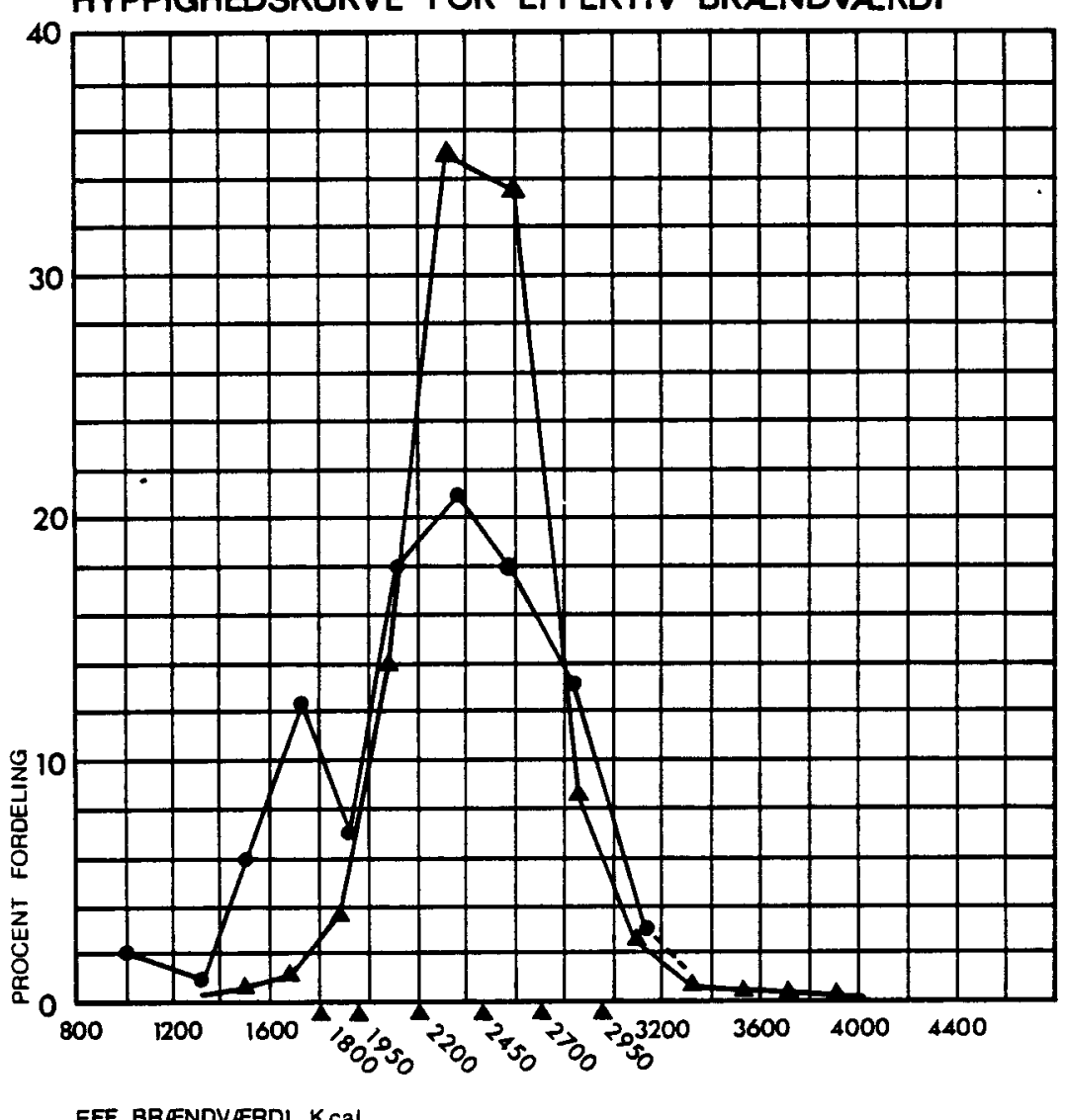

EFF: BRENDVAERDI $\mathrm{Kcal}$

$\longrightarrow \quad \begin{gathered}\text { Analyser II kampagne (antal 13035) } \\ \text { (Mogensen 1953) }\end{gathered}$

Analyser III kampagne (antal 411) 
FIG. 15

HYPPIGHED FOR BRAENDVAERI AF BRENDBART STOF

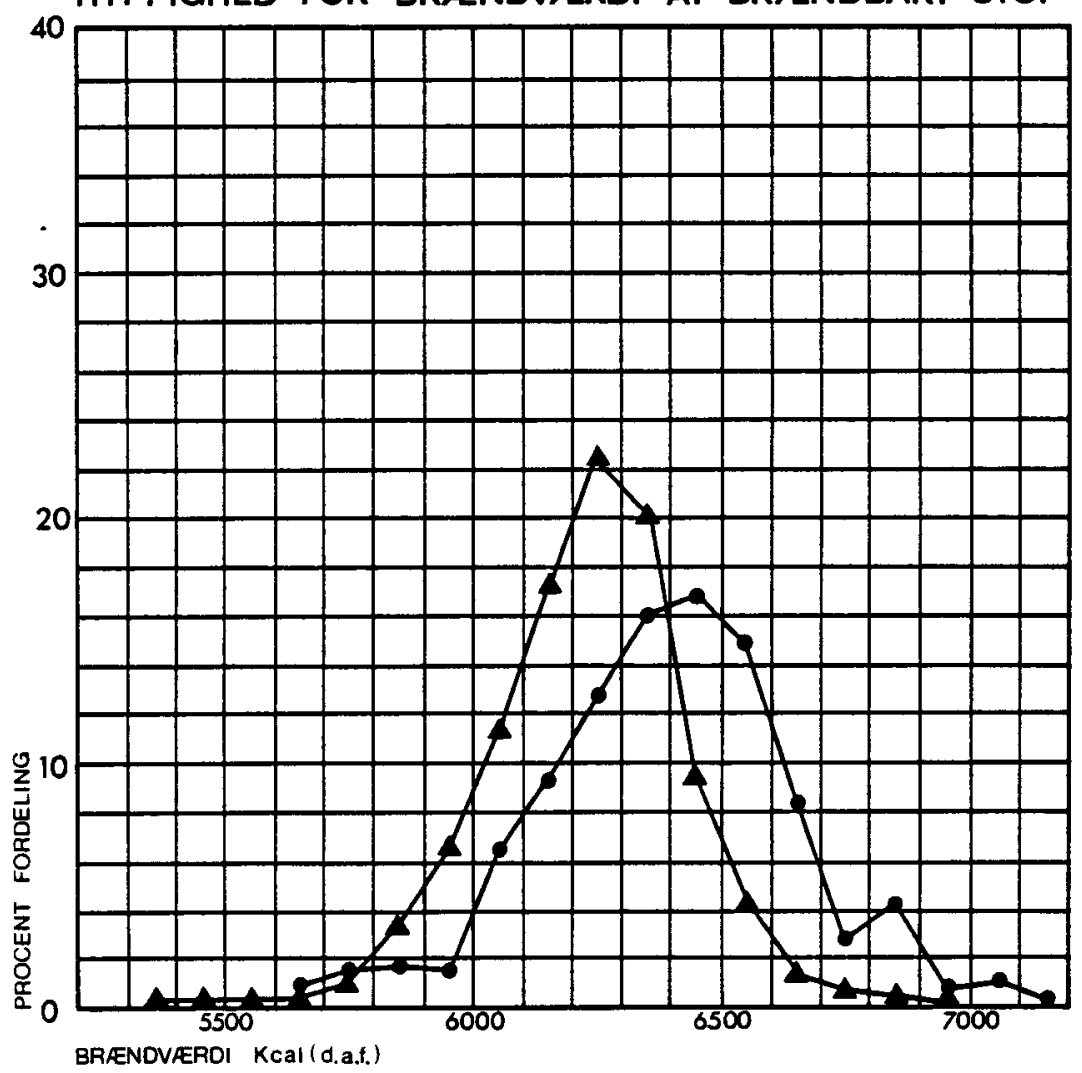

Analyser II kampagne (antal 13035)

(Mogensen 1953)

Analyser III kampagne (antal 362 ) 
FIG. 16

HYPPIGHED FOR SVOVLPROCENTEN

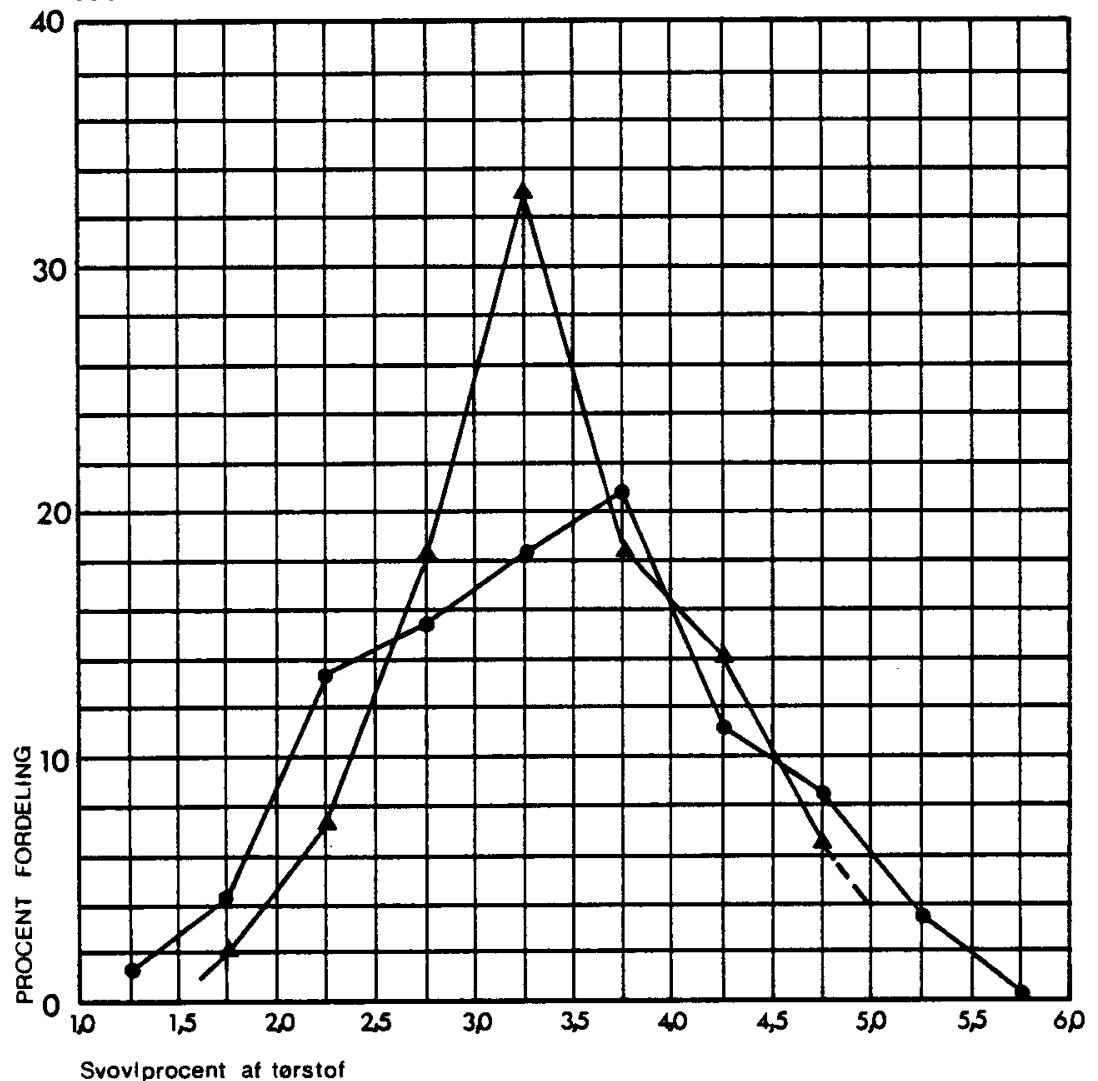

Analyser II kampagne (ant al 100)

(Mogensen 1953)

Analyser III kampagne (antal 366) 


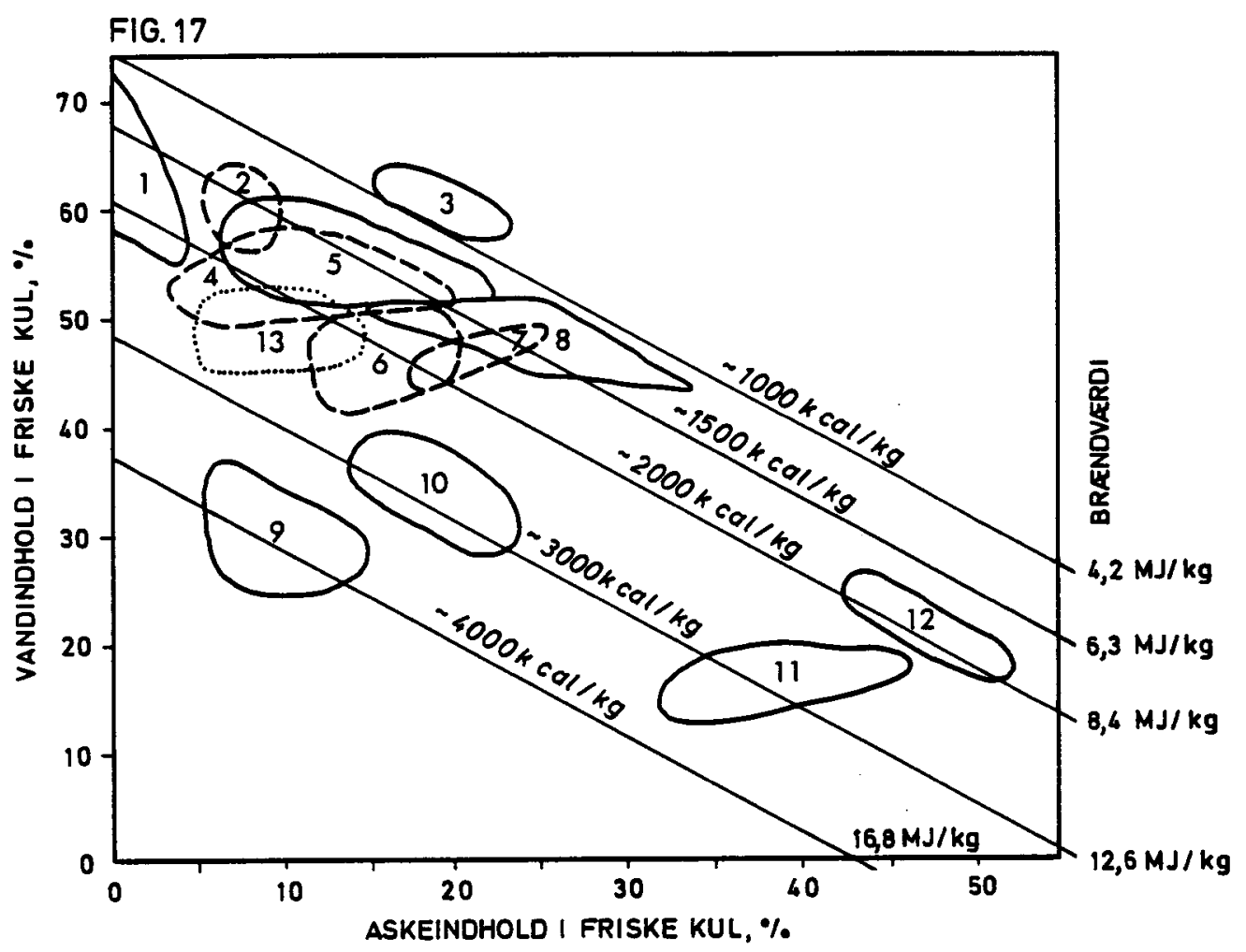

1. Yallourn, Australien

7. Puentes, Spanien

2. Hagenwerder, $\emptyset$. Tyskland 8. Gyongyos, Ungarn

3. Megalopolis, Grækenland 9. Dakota, Texas, USA

4. Neurath, W. Tyskland 10. Aliveri, Grakenland

5. Ptolemais, Grækenland 11. Bobov Dol, Bulgarien

6. Turow, Polen

12. Tuncbilec, Tyrkiet

13. Danske brunkul

Kvalitetsvariation for brunkulsforekomster 


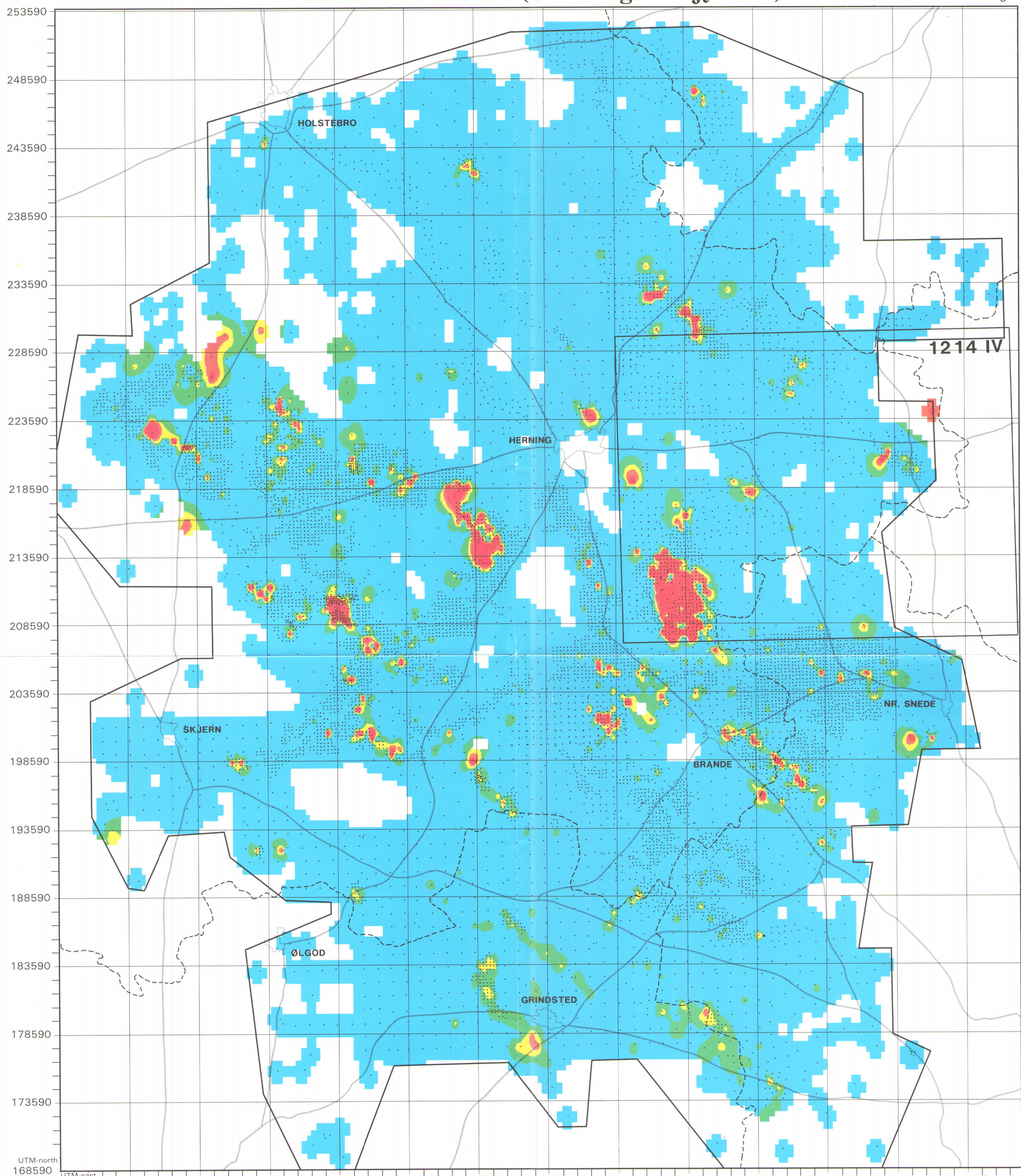

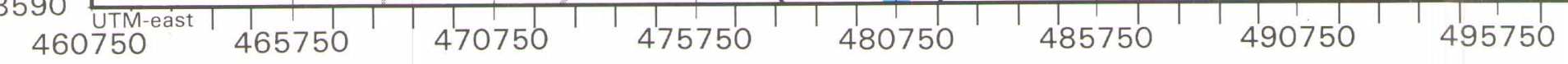
Summeret lagtykkelse Legende:

I Danmark har brunkul været anvendt som brændsel til el- og varmeproduktion frem til 1972. Under og efter 1. og 2. verdenskrig og i perioden $1958-63$ er der udført knapt 14.000 systematiske boringer efter brunkul. Boringerne er edb-bearbejdet.

Kortet viser hvor der i Midt- og Vestjylland via boringer er registreret forekomster af brunkul. En mindre del af 列 til en samlet kultykkelse. Det er denne kultykkelse og beliggenhed, som er vist på kortet.

Brunkullene i Danmark er geologisk set fra miocæn epoken i den tertiære periode og 15-20 mill. år gamle.

\begin{tabular}{|l|}
\hline Over 1,8 \\
$1,4-1,8$ \\
$1,0-1,4$ \\
$0,6-1,0$ \\
$0,2-0,6$ \\
Under 0,2 eller intet \\
udefineret
\end{tabular}

:Begrænsning af området med systematiske brunkulsboringer Amtsgrænse

:Boring 


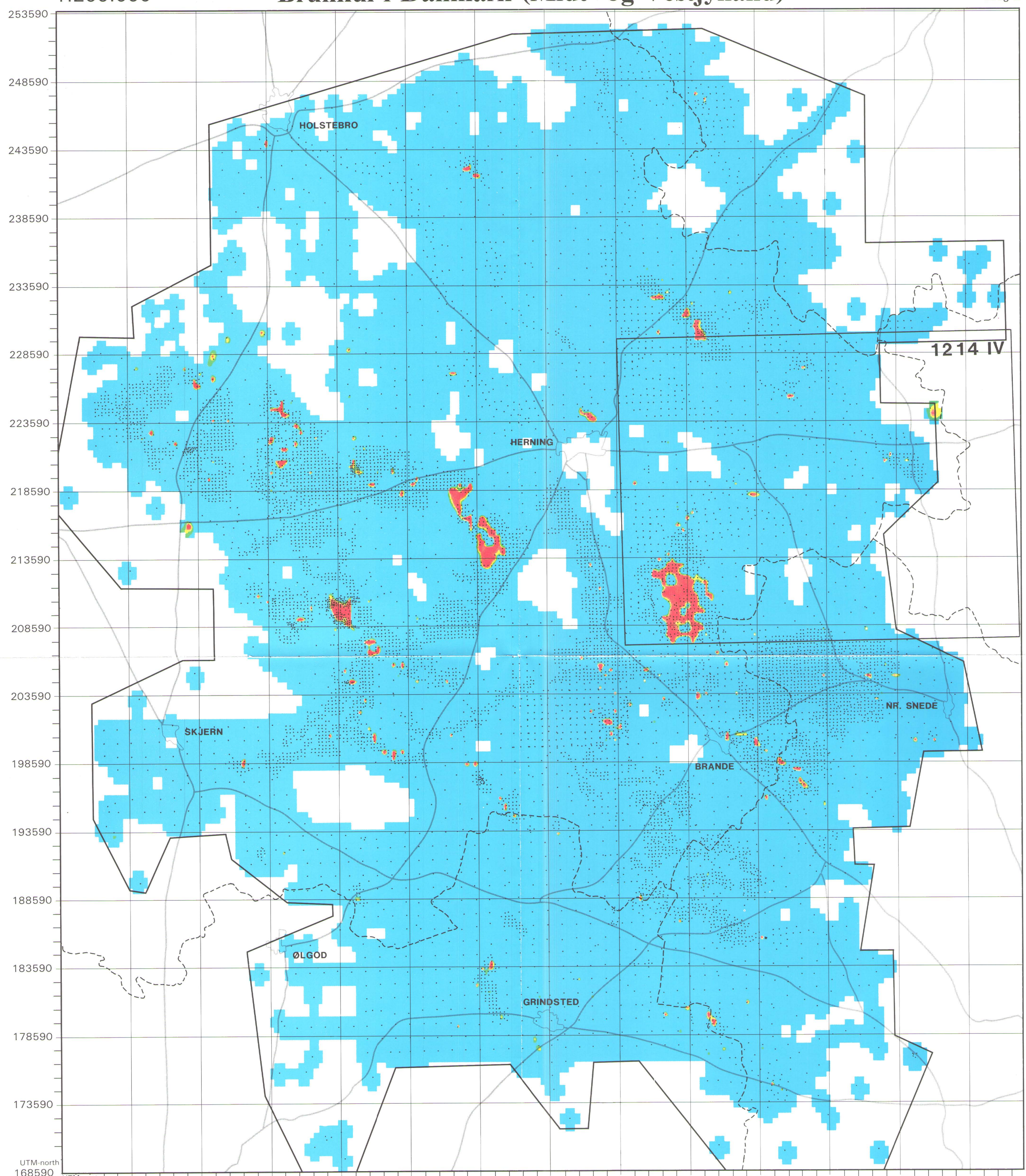

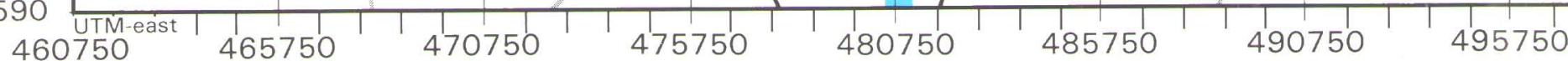

Graveindex for brunkul:

I Danmark har brunkul været anvendt som brændsel til el- og varmeproduktion frem til 1972. Under og efter 1. og 2. verdenskrig og i perioden 1958-63 er der udført knapt 14.000 systematiske boringer efter brunkul. Boringerne er edb-bearbejdet.

I vurderingen af rentabiliteten ved udnyttelse af brunkul, er det af interesse at vide hvor meget materiale der skal fjernes før brunkullene kan opgraves og anvendes. Et talmæssigt udtryk herfor er et såkaldt graveindex. I den enkelte boring, er brunkulslag over $0.2 \mathrm{~m}$ til en dybde af $30.0 \mathrm{~m}$ summeret til en samlet brunkulsmængde. Graveindexet udtrykker forholdet mellem overjorden og brunkulsmængden. Eksempelvis giver brunkul i 12 meters dybde $i$ en tykkelse på 1 meter et graveindex på 12:1 eller blot 12 .

På kortet er vist variationen i graveindex.

Brunkullene i Danmark er geologisk set fra miocæn epoken i den tertiære periode og 15-20 mill. år gamle. KORTET FREMSTILLET AF: Allan Grambo-Rasmussen/Sten Aabo Hansen
Legende:

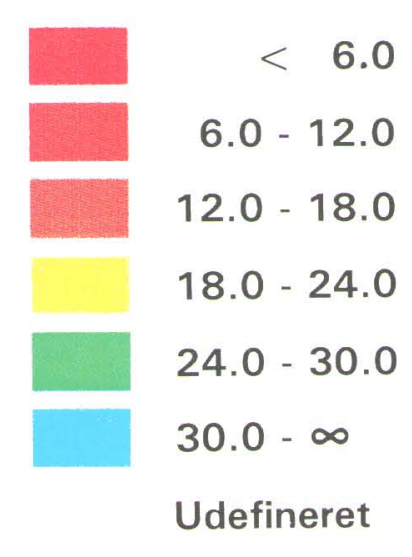

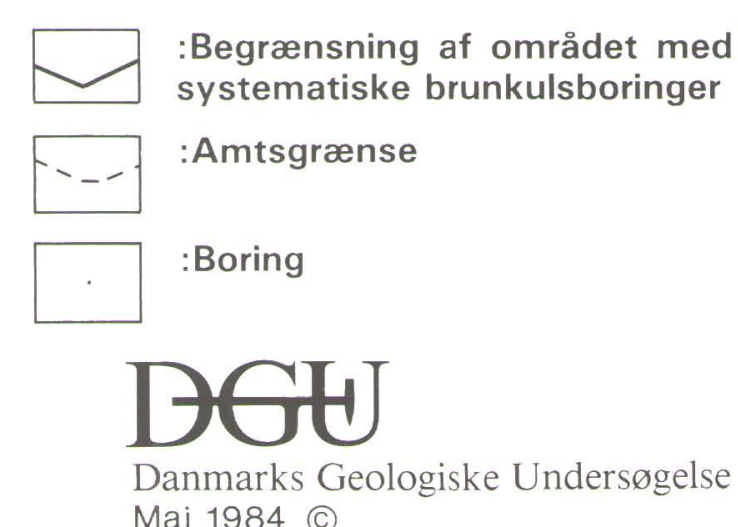



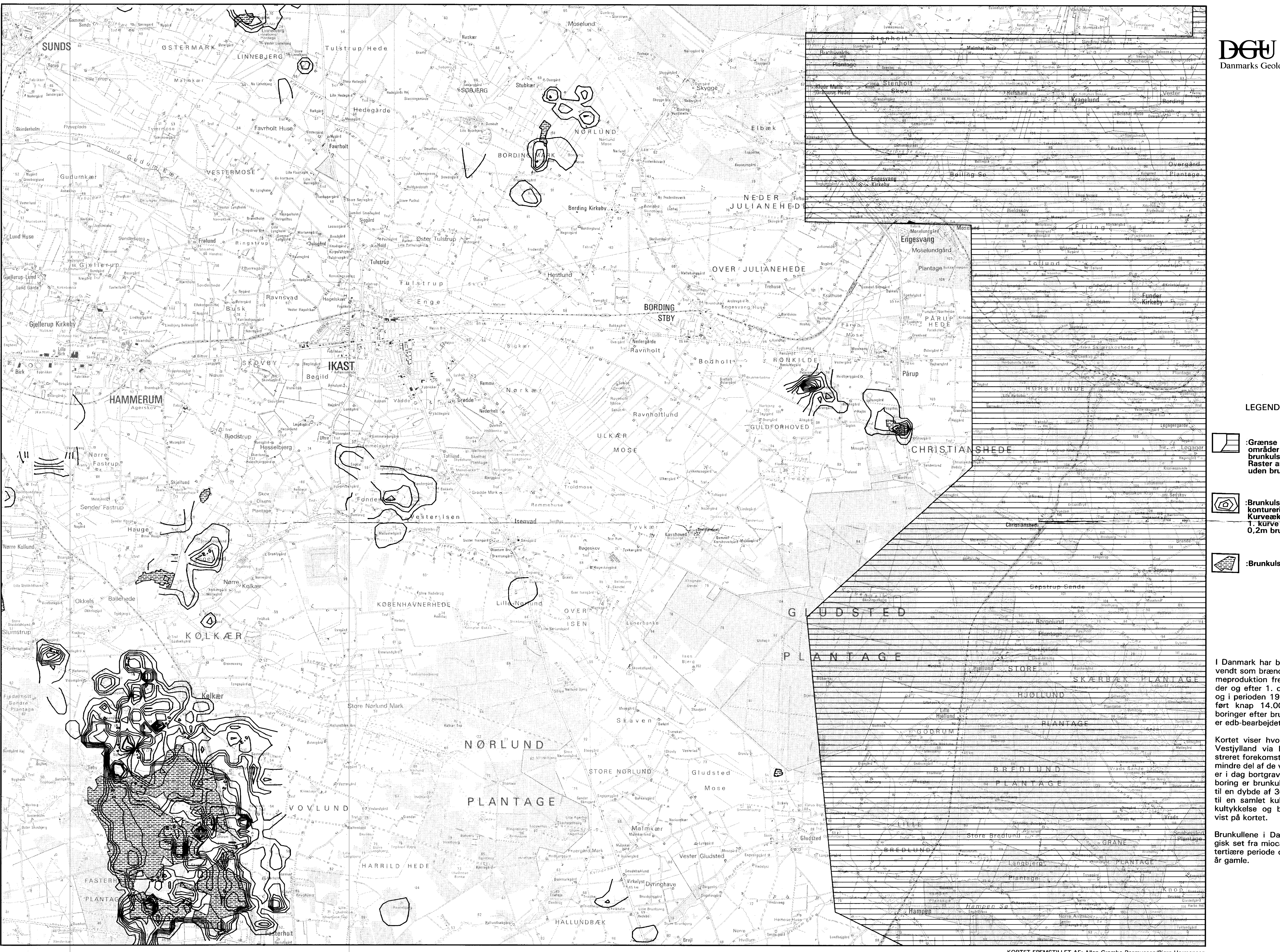

BRUNKULSFOREKOMSTER uden anvendelse af graveindex

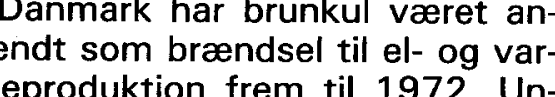

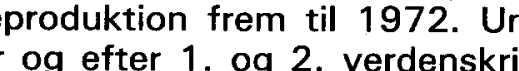

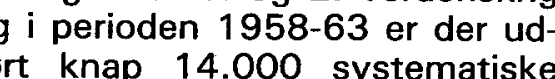
boringer efter brunkul. Boringerne
Sedb-bearbejidet

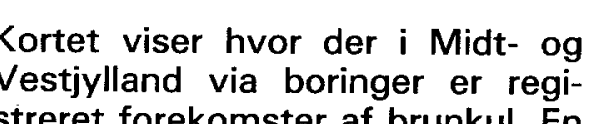

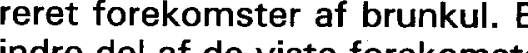

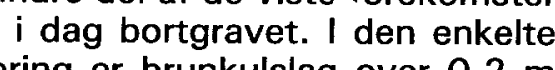

en dybde at $30.0 \mathrm{~m}$ summere
en samite kultykkelse. Denn

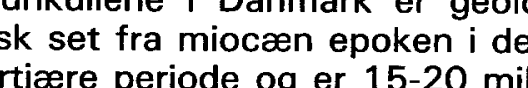




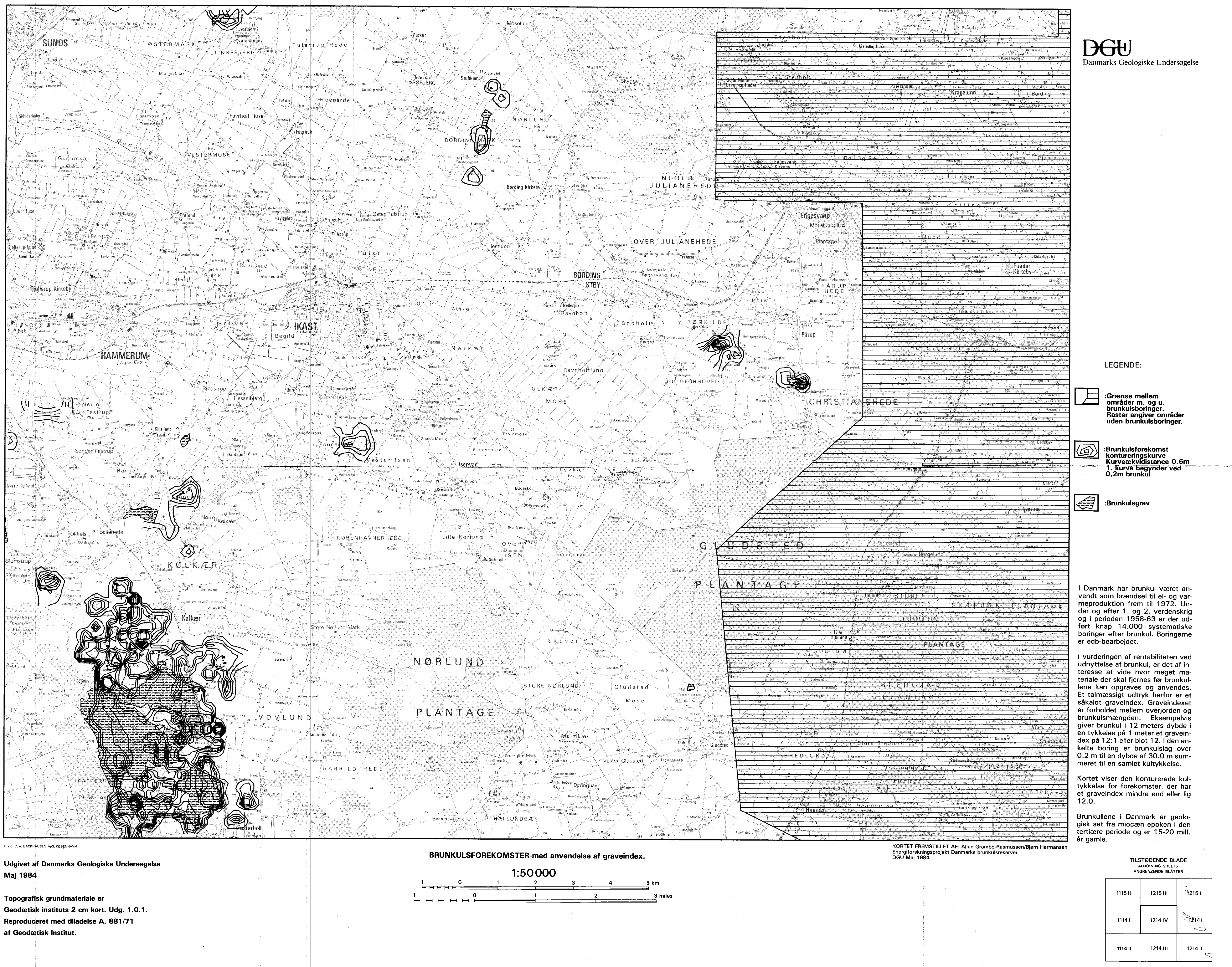


I Danmark findes brunkulsforekomster i Midt- og Vestjylland. Generelt forekommer brunkulslagene i dybder fra $15-25 \mathrm{~m}$ og med lagtykkelser på få millimeter og op til 3-4 m. I 1921 og under og efter 2. Verdenskrig, samt i perioden 1958-63 udførte Danmarks Geologiske Undersøgelse (DGU) systematiske boringer efter brunkul. Boringerne er registreret og arkiveret på instituttet. I september 1980 startede DGU et fasedelt projekt financieret af energiforskningsprojektets penge (EFP-midler). Projektet har ved brug af moderrie edb-teknik behandlet det arkiverede materiale med henblik på beliggenheden, mængden og kvaliteten af brunkulsforekomsterne.

Danmarks Geologiske Undersøgelse

Thoravej 31

DK 2400 København NV

Danmark

Telefon 01106600 